\title{
INVESTOR PROTECTION AND THE DEMAND FOR EQUITY*
}

\author{
Mariassunta Giannetti \\ Department of Finance and SITE \\ Stockholm School of Economics \\ and CEPR
}

\author{
Yrjö Koskinen \\ Department of Finance \\ Stockholm School of Economics \\ and CEPR
}

SSE/EFI Working Paper Series in Economics and Finance no. 526

February 2004

\begin{abstract}
*The authors are grateful to Arturo Bris, Mike Burkart, Hans Degryse, Maria Gutierrez, Alan Morrison, Fred Palomino, Michael Rebello, and seminar participants at the 2003 EFA meetings, the ECB Conference on Capital Markets and Financial Integration in Athens, the CEPR Conference on the Evolution of Corporate Governance and Family Firms at INSEAD, the Stockholm School of Economics, Universidad Carlos III, Indiana-Bloomington, Norwegian School Management and HEC Lausanne for helpful comments, and to David Parsley for providing the distance data. The authors also acknowledge financial support from the Bank of Sweden Tercentenary Foundation and the Tom Hedelius and Jan Wallander Foundation. This paper is produced as part of a CEPR Research Network on "Understanding Financial Architecture: Legal and Political Frameworks for Economic Efficiency" funded by the European Commission under the Research Training Network Programme (Contract No: HPRN-CT-2000-00064). Correspondence to: Stockholm School of Economics, Sveavägen 65, Box 6501, SE-113 83, Stockholm, Sweden. E-mail: mariassunta.giannetti@hhs.se or yrjo.koskinen@hhs.se. Phone: +46-8-736 9607 (Giannetti) or +46-8-736 9145 (Koskinen). Fax: +46-8-312 327.
\end{abstract}




\begin{abstract}
Anecdotal evidence suggests that investor protection affects the demand for equity, but existing theories emphasize only the effect of investor protection on the supply of equity. We build a model showing that the demand for equity is important in explaining financial development. If the level of investor protection is low, wealthy investors have an incentive to become controlling shareholders and pay a high price for their stocks, because they can earn additional benefits by expropriating outside shareholders. As a consequence of lower expected returns both domestic and foreign portfolio investors have a disincentive to hold stocks. The model implies that differences in stock market participation rates across countries and the pervasiveness of home equity bias depend on the degree of investor protection. Additionally, we uncover a good country bias in investment decisions as portfolio investors from countries with low level of investor protection hold relatively more foreign equity. We provide novel international evidence on stock market participation rates, and on holdings of domestic and foreign stocks consistent with the predictions of the model.
\end{abstract}

JEL codes: G11; G32; G38; F21; F36.

Keywords: Investor Protection; Private Benefits of Control; Portfolio Choice; Home Equity Bias; Limited Participation. 
"I simply would not buy a company with poor corporate governance".

CFO, USD 3bn European Private Bank

(quoted by McKinsey\&Company, 2003a)

\section{Introduction}

Extraction of private benefits of control by company insiders is a well-known distortion in corporate finance. A vast literature initiated by La Porta et al. (1997 and 1998) has established that the weaker the protection of minority shareholders is, the stronger are controlling shareholders' incentives to expropriate part of the returns as private benefits of control. Both theory and empirical evidence clearly demonstrate that the distortions caused by extraction of private benefits of control have significant effects on firms' cost of external funds and investment decisions (Shleifer and Wolfenzon, 2002). It is by now well accepted that weak investor protection increases the cost of external funds, and the cost of equity in particular. Hence, in countries where investors are poorly protected firms issue less equity and capital markets are underdeveloped. Put differently, poor investor protection affects the supply of equity negatively.

Researchers have focused less attention on how investor protection affects the demand for equity, as investors are assumed to provide any amount of funds as long as they are appropriately compensated for the risk they bear. Practitioners, however, seem to believe that the demand for equity is affected by investor protection. In two recent surveys McKinsey\&Company (2003a and b) reports that domestic and foreign portfolio investors put corporate governance considerations at the heart of their investment decisions. Investors claim that they decrease their holdings or even avoid investing in countries or companies, which are perceived to provide poor investor protection. This is not that surprising after all, since investor protection affects how a firm's cash flows are divided between security benefits, which accrue to all shareholders pro-rata, and private benefits, which only the controlling shareholders have access to. This division in turn affects the prices that different classes of investors are willing to pay for their stocks. If some investors can gain access to both private and security benefits, then those investors are willing to pay more for a stock than investors who can only enjoy the security benefits. To the extent that the market price of stocks reflects the demand from controlling shareholders, all other shareholders find the price too high and hence the expected returns are too low. As a consequence, outside shareholders reduce their demand. 
This paper aims to show that investor protection has an impact on financial development also by affecting the demand for equity. We study how investor protection affects the portfolios of different classes of investors, depending on the amount of wealth they have been endowed with. We show that in countries with low levels of investor protection, where private benefits of control are larger, wealthy investors find it optimal to forgo diversification benefits in order to acquire control of domestic firms. The extraction of substantial control benefits diminishes the security benefits available to all outside investors and thus reduces the incentives to invest in stocks for those shareholders who are not wealthy enough to acquire large equity stakes and to participate in the extraction of private benefits of control. In other words, the expected return of holding stocks is lower than it would be in the absence of expropriation of private benefits of control for outside investors, because wealthy investors have bid up the prices in their quest for control benefits. This results in fewer investors willing to buy stocks and financial markets remain underdeveloped.

Using a simple two-country general equilibrium model, we show that this mechanism generates interesting empirical implications on the extent to which investors participate in equity markets and diversify their portfolios internationally. Weak investor protection unequivocally reduces the incentives to participate in the domestic stock market for all - domestic and foreign - outside investors, because stock prices also reflect the high demand from controlling shareholders and thus expected returns of holding stocks are lowered for outside investors. Hence, foreign investors from a country where investors are better protected prefer to invest in their own country, leading to the familiar home equity bias. In contrast, domestic non-controlling investors are interested in investing in foreign countries that have better investor protection laws than their home country. To put it differently, these investors are less prone to participate in the domestic market and exhibit a good country bias. In the aggregate, however, we expect the home equity bias to hold in all countries. The reason is that in equilibrium wealth distribution within a country is as important as the quality of its investor protection in explaining the extent of private benefits of control extraction. Portfolio investors have the largest incentive to avoid investing in their own country when they have the least amount of relative wealth. As a result, the country as a whole exhibits a preference for its own stocks, because the dominant wealthy investors control larger amounts of wealth and have an incentive to invest in their own country. Large shareholders' home equity bias overwhelms the good country bias of domestic portfolio investors in aggregate data.

Besides contributing to explain the home equity bias, our model suggests that cross-country differences in investor participation in the domestic stock market (see Guiso et al., 2002, for some 
recent empirical evidence) depend on investor protection. In this respect, it also helps to explain the limited participation puzzle (i.e., why most households do not invest in stocks). The model highlights the similarities in the behavior of domestic and foreign investors, thus suggesting that home equity bias and limited participation puzzle are related.

In our model, lower level of investor protection increases ownership concentration because wealthy domestic investors - being able to enjoy larger private benefits - are willing to invest more in their own country if investors are not well protected. In equilibrium, however, it is not necessarily true that a country with worse investor protection has higher ownership concentration, because the initial distribution of wealth is as important as investor protection in determining ownership structure and extraction of private benefits. If wealth distribution is very even nobody may be wealthy enough to be able to acquire control and extract private benefits. Hence even if investor protection is low, participation in the domestic stockmarket and return on equity for portfolio investors may be high. Conversely, improvements in investor protection are not sufficient to spur equity market participation if the wealth distribution is very skewed.

Changes in wealth distribution can also explain why the relation between ownership concentration and investor protection is weaker or does not hold if long periods of time are considered. Morck et al. (2004) report that in Canada at the beginning of the 1900's ownership was highly concentrated and investor protection poor. By the middle of the century, however, widely held firms had become predominant, even though investor protection had not improved. This finding is less surprising if one takes into account that in the same period an expanding middle class capable of investing in stocks emerged. Our model suggests that the demand for stocks by the middle class increased stock prices and this in turn made it optimal for controlling shareholders to reduce their equity-holdings. Morck et al. (2004) also show that the prevalence of widely held firms in Canada has declined starting from the 1970's. This coincides with the abolition of the inheritance tax in Canada and widening inequalities of wealth.

The implications of our model are also compatible with the experience of Italy in the same period (see Aganin and Volpin, 2004). More in general, Rajan and Zingales (2003) show that there was a great reversal in financial development in Europe, where financial markets were well developed before the World War I and deteriorated afterwards. The negative impact of the Great Depression on the middle class incomes in Europe can contribute to the explanation why this reversal happened.

By explicitly considering the effect of initial wealth on the demand for stock, we are also 
able to provide a new counterintuitive explanation why firms with more concentrated ownership structures have higher valuations. The standard explanation for higher valuations for companies with concentrated ownership is based on partial equilibrium analysis, where large ownership stakes provide incentives to monitor either the managers or other principal shareholders, and as a result firm cash flows and valuations are increased (see, for instance, Morck et al., 1988 and McConnell and Servaes, 1990). Our explanation in a general equilibrium framework is based on increased demand from wealthy investors: In order to acquire control in domestic companies and enjoy the consumption of private benefits of control, wealthy investors may have high demand for domestic stocks. As a result, stock prices may be high. Empirically we then could observe that there is a positive correlation between ownership concentrations and company valuations, even if expected cash flows have not increased.

Finally, we explore the empirical relevance of the demand for equity channel by testing the equilibrium implications of our model for investors' portfolios. We find that cross-country differences in portfolio choices are indeed related to differences in investor protection. First, fewer individuals participate in the domestic stock market in weak investor protection countries. Second, in weak investor protection countries, domestic investors' portfolio holdings of foreign relative to domestic equity are larger than in countries where minority shareholders are better protected. Finally, we find evidence of a good country bias: Using a novel dataset offering information on the portfolio holdings of institutional investors from a large cross-section of countries we find that portfolio investors from countries where investor rights are poorly protected are more likely to invest in foreign countries. Moreover, they have a preference for countries providing strong protection of shareholder rights, even after controlling for variables measuring stock market development in the destination country and the supply of financial assets in the home country.

The remainder of this paper is organized as follows. Section 2 relates the paper to the literature. Section 3 presents the model and section 4 describes the equilibrium implications. Section 5 provides some cross-country empirical evidence supporting the implications of the model. Section 6 concludes.

\section{Related literature}

This paper is related to three main strands of literature: the law and finance literature, the home equity bias literature, and the literature on limited investor participation in stock markets. First, 
as we noted before, this paper is related to the large and growing strand of literature initiated by La Porta et al. (1997 and 1998). ${ }^{1}$ They show that the size and scope of capital markets are positively related and that ownership concentration is negatively related to investor protection. Moreover, they also show that companies with controlling shareholders are very common around the world (La Porta et al., 1999). Typically, the literature on law and finance has emphasized how minority shareholders are protected in the corporate law. However, securities law may be as important for the functioning of financial markets. Glaeser et al. (2001) argue that differences in securities law was the decisive factor in explaining why Poland was more successful than the Czech Republic in developing stock markets after the fall of socialism. In a recent paper La Porta et al. (2003) show that securities market law may be even more important than corporate law in explaining the development of financial markets.

Our paper is closest to Shleifer and Wolfenzon (2002), who show that companies have higher valuation and ownership is less concentrated in countries with better investor protection. There are, however, important differences between Shleifer and Wolfenzon (2002) and our paper: Shleifer and Wolfenzon (2002) focus on the implications of investor protection on corporate financing and investment, while we aim to analyze investors' portfolio choices. For this reason, we model explicitly the portfolio decisions of risk averse investors and how the decisions are affected by the relative magnitude of security and control benefits in countries with different levels of investor protection. As a consequence in our model, controlling shareholders emerge endogenously in equilibrium, while less wealthy investors may opt out of the market. As a contrast, Shleifer and Wolfenzon (2002) model a going public process, where the existence of a controlling shareholder is assumed, and outside investors are risk neutral and provide funds as long as their participation constraint is satisfied. The strategy we choose may be more appropriate in analyzing changes in ownership structure for companies that are already listed in a stock market.

Our paper is also related to cross-country studies by Dyck and Zingales (2003) and Nenova (2003), who show that some investors are willing to pay a lot for control rights that give access to private benefits. $^{2}$

Second, this paper is also related to a large literature that studies, separately, home equity bias and limited participation puzzle. Home equity bias is one of the least contested empirical facts in finance (for a recent survey, see Lewis 1999). Under standard assumptions from portfolio theory and absent legal restrictions, investors should hold the world portfolio. Empirically, however, this is not the case. Empirical studies document that home bias holds for very diverse countries ranging from 
the developed financial markets of the U.S. to small markets like the Scandinavian ones, all the way to less developed emerging markets. ${ }^{3}$ There exist several other explanations for the home equity bias besides the explanation provided in this paper. Legal restrictions were an important factor when there were binding restrictions on international capital flows, but home bias has persisted even though legal restrictions on foreign ownership have disappeared. Also foreign investments may be taxed more harshly than domestic investments. ${ }^{4}$ However, as argued by Ahearne et al. (2001), legal restrictions and taxes are of secondary importance in explaining the home equity bias. In international finance, the most widely cited reason for home equity bias is based on asymmetric information. Domestic investors are assumed to know more about domestic stocks than foreign investors leading to increased investments in domestic equities. ${ }^{5}$ This explanation can, however, be challenged. Informational advantage could be in fact the opposite in some cases: it can be argued that large foreign portfolio investors are more sophisticated and therefore better informed than small domestic investors. Consistent with this assumption Grinblatt and Keloharju (2000) show using Finnish data that foreign investors have outperformed domestic investors.

In a recent paper Dahlquist et al. (2003) relate home equity bias to corporate governance, as we do. In their paper deficiencies in investor protection lead to larger shareholdings by inside owners. This then leads to diminished availability of shares to foreign investors. We view the Dahlquist et al.'s (2003) paper as complementary to ours. Dahlquist et al. (2003) concentrate on the supply of stocks and on the agency conflict between managers and all investors. We, on the contrary, concentrate on the demand for stocks and on the agency conflict between inside and outside investors. In addition to this we are able to explain why some investors prefer to opt out of the stock market and uncover a good country bias in portfolio investors' shareholdings.

Finally, this paper is related to the literature on limited participation, which has also been widely studied in the asset pricing literature (see, for instance, Mankiw and Zeldes, 1991; VissingJorgensen, 2002; and Brav et al., 2002). ${ }^{6}$ All papers in this literature, however, explore the implications of low degree of household participation in the stock market within a single country. Only recently, Guiso et al. (2001 and 2003) have showed that there are significant cross-country differences in investor participation rates. The phenomenon has lacked a theoretical justification and this paper is the first one to provide an explanation for that. 


\section{The model}

In our model, there are two countries that differ in the quality of investor protection. For simplicity, we have only one risky asset with a random payoff in each country in addition to a riskless asset. We assume that all investors pay the same market clearing price for the risky asset in each country. Allowing only one market clearing price for the risky asset abstracts from the issue of multiple share classes and block trading. This assumption is not crucial for our analysis. Only if the price discrimination between investors with and without control were perfect, would the demand effect our model is based on loose its relevance. As long as controlling investors also trade in the open markets, the demand from such investors increases the stock price and reduces the demand from outside investors, as we show in the model.

In both countries there are heterogenous investors that differ on the amount of wealth they have been endowed with. The initial wealth distributions, the quality of investor protection and the distribution of asset returns in both countries are common knowledge. Investors are risk averse and are free to invest in risky assets in both countries after having paid a fixed participation fee. There is no participation fee when investors invest in the risk free asset. When investing, all investors take prices as given. Investors can become controlling investors by acquiring a large enough ownership stake in their domestic risky asset.

No short sales or borrowing are allowed. No short sales and no borrowing imply that only investors endowed with a lot of wealth can become controlling investors. Only domestic investors

who become controlling investors are able to extract private benefits of control. ${ }^{7}$ The incentive to become a controlling investor depends on how easy it is to extract private benefits of control, in other words how well other investors' cash flow rights are protected. The extraction of private benefits of control reduces the cash flows that are available to all investors and, therefore, affects less wealthy domestic investors' and foreign investors' decisions to hold risky assets. In what follows, we describe the model in detail.

\section{A Timing}

- At $t=0$, domestic and foreign investors make their portfolio decisions.

- At $t=1$, before the random payoffs are realized, investors who have acquired control rights have the opportunity to extract private benefits of control.

- At $t=2$, payoffs net of private benefits of control are distributed to all investors. 


\section{B Investment opportunities}

There are two symmetric countries, called Home and Foreign. The following describes the Home economy. The Foreign economy is to be considered completely symmetric, unless stated otherwise. Foreign variables will be denoted with an asterisk. A risky asset with gross random payoff $\widetilde{X}\left(\widetilde{X}^{*}\right.$ in Foreign) is available in both countries. The expected payoff of the domestic (foreign) risky asset is $\mu_{X}\left(\mu_{X}^{*}\right)$ and the variance is $\sigma_{X}^{2}\left(\sigma_{X}^{*}\right)$. The payoffs of the two assets are positively correlated and the correlation coefficient $\rho$ is strictly less than 1 . The price of the domestic (foreign) risky asset is denoted by $P\left(P^{*}\right)$ and is determined endogenously in equilibrium. All assets are available in fixed supply, which we normalize to be 1 , and are owned initially by the domestic investors of the two countries. Investors have also access to a risk-free storage technology, identical in both countries, which provides zero return. We think of this as cash and deposits and will generally refer to it as the risk free asset.

\section{Investors}

Both countries have heterogeneous investors, who differ in the amount of their initial wealth, $W_{0}$. We assume that their wealth consists of a share of $w_{0}$ of the domestic wealth. Total domestic wealth is $1+P$ in Home and $1+P^{*}$ in Foreign. The initial share of wealth $w_{0}$ is distributed between 0 and

$\bar{w}_{0}$, and satisfy the condition $\int_{0}^{\bar{w}_{0}} w_{0} d F\left(w_{0}\right)=1$, where $F$ is the cumulative density function of the distribution of initial wealth. Investors can allocate their initial wealth $W_{0} \equiv w_{0}(1+P) \quad\left(W_{0}^{*} \equiv\right.$ $w_{0}^{*}\left(1+P^{*}\right)$ in Foreign) between the risk free asset, domestic and foreign risky assets. We assume that investors cannot borrow in order to invest in the stock market, nor can they sell stocks short.

In our model buying a risky asset is equivalent to participating in the stock market. Following the existing literature (see, for example, Vissing-Jorgensen, 2002) we assume that buying a risky asset entails a fixed participation cost, denoted by $c$. This cost can be thought of comprising of transaction costs, costs of getting informed about how the stock market operates, and other costs involved in having to keep track of one's own stocks. Investing in both the domestic and foreign markets is more expensive than investing in one market only, as investors may have to keep a domestic and a foreign security account, and follow news regarding different markets. We capture this by assuming that investors pay a separate cost for participating in the domestic and foreign markets. The cost is assumed to be equal for both markets.

Domestic investors who own a large stake in domestic companies may enjoy private benefits 
of control in addition to the security benefits, which are shared equally by all investors. We assume that foreign investors are not able to extract private benefits of control, and that controlling shareholders who invest abroad act like ordinary portfolio investors. The main reason we make this assumption is that foreign equity-holdings that have a control motive are classified as foreign direct investment and are not included in the portfolio investments in the literature on home equity bias to which we want to relate (see, for instance, Ahearne et al., 2001). This assumption can also be supported by the fact that dealing with local courts and corrupted bureaucrats - often necessary if an investor wants to enjoy private benefits of control - is easier for domestic investors, who know the local culture. Consistent with this, there is empirical evidence that the flow of foreign direct investments is significantly lower to countries with poor investor protection (Wei, 2000 and Wei and $\mathrm{Wu}, 2001)$. Furthermore, in countries with high level of corruption and poor rule of law, foreign direct investments are generally carried out as joint ventures with local partners (Smarzynska and Wei, 2000).

We assume that in order to divert cash flows and enjoy private benefits of control, shareholders have to own a fraction $\alpha$ of the shares that is larger than a threshold of $\underline{\alpha}$, i.e. $\alpha \geq \underline{\alpha}$. Since we have normalized the supply of the risky assets to be $1, \alpha$ denotes both the fraction of shares held in a company and the quantity invested in the company. We also assume that $\underline{\alpha}$ is larger than the share an investor would find it optimal to invest in the absence of control benefits.

We refer to the investors who own more than $\underline{\alpha}$ as the controlling shareholders $(C S)$ and denote their domestic and foreign shareholdings as $\alpha_{C S}^{H}$ and $\alpha_{C S}^{F}\left(\alpha_{C S^{*}}^{F}\right.$ and $\alpha_{C S^{*}}^{H}$ for the controlling shareholders in Foreign). The emergence of controlling shareholders will be determined endogenously. A company may have several controlling shareholders. If a company has several controlling shareholders, we assume that all controlling shareholders collude in expropriating outside shareholders, i.e. that are no conflicts of interest between different controlling shareholders ${ }^{8}$. We refer to investors without control as portfolio investors (PI) and denote their domestic and foreign shareholdings as: $\alpha_{P I}^{H}$ and $\alpha_{P I}^{F}\left(\alpha_{P I^{*}}^{F}\right.$ and $\alpha_{P I^{*}}^{H}$ for portfolio investors in the Foreign country).

We assume that the extraction of private benefits of control reduces the cash flow available to all investors. We define $B$ as the amount of cash flows controlling shareholders divert. For simplicity, we assume that $B_{\max }<X_{\min }$, where $B_{\max }$ is the maximum level of cash flow that is possible to be diverted and $X_{\min }$ is the lower bound of the support for the payoffs from the risky technology. This assumption implies that even when the realized payoffs are low there is always some output that can be extracted by the controlling shareholders. ${ }^{9}$ The private benefits that controlling shareholders 
can enjoy depend on their ownership shares of the risky asset and the quality of investor protection, $\lambda$. Let $g(\lambda, B)$ denote the function that describes the technology of private benefit extraction. For $B$ units of cash flow diverted, the amount of private benefits that is consumed is $g(\lambda, B) \alpha_{C S}^{H}$. We make the following assumptions:

1. $g(\lambda, 0)=0, g_{B}(\lambda, B)>0, g_{B}(\lambda, 0)=\infty, g_{B}\left(\lambda, B_{\max }\right)=0$ and $g_{B B}(\lambda, B)<0$. This set of assumptions is similar to those made in Burkart et al. (1998). They imply that extraction of private benefits of control becomes less efficient as the amount of cash flow diverted increases. For our results to hold, extraction of private benefits does not need to be necessarily inefficient (i.e., $\left.\alpha_{C S}^{H} g(\lambda, B) \lessgtr B\right)$.

2. $g_{\lambda}(\lambda, B)<0$ and $g_{B \lambda}(\lambda, B)<0$. The better protected investor rights are (the higher is $\lambda$ ), the lower are the private benefits controlling shareholders can enjoy. Additionally, it is more difficult to consume high levels of private benefits of control in countries with better investor protection laws.

3. The higher is the ownership share of a controlling shareholder $\alpha_{C S}^{H}$, the more she can enjoy private benefits of control. This captures the entrenchment effect: if the ownership stake of a controlling shareholder is large, it is very hard to stop her from extracting private benefits of control, for instance because it is more difficult to remove her. ${ }^{10}$

Our extraction technology introduces the entrenchment effect of ownership concentration by assuming that private benefits of control increase linearly in $\alpha_{C S}^{H}$. The entrenchment effect has so far being neglected in the theoretical literature, but may be as important as the incentive effect of ownership concentration. In fact, the empirical literature has failed to find a stable relation between ownership concentration and firm value and the opposite effects of incentive and entrenchment effects on firm value may be the reason for this empirical ambiguity (Denis and McConnell, 2003). Also in a recent paper using data from U.S. dual-class common stock companies Gompers et al. (2004) find that corporate valuations are increasing in cash flow rights that insider owners hold, but that the relationship is negative with respect to the voting rights the insiders have. This finding is consistent with the view that both incentive and entrenchment effects of ownership concentration are important.

An advantage of the extraction technology we assume is that it allows us to study the equilibrium implications of the entrenchment effect. For such an effect to exist, we only need the assumption 
that the extraction of private benefits becomes easier when the controlling shareholder has more control rights. The assumption that the extraction technology increases linearly in the control stake is made only to be able to derive simple closed form solutions.

All investors maximize the expected utility from final period wealth, and have an utility function that is quadratic in the monetary wealth $\widetilde{W}$. The utility also depends positively on the private benefits of control that controlling shareholders enjoy. From the point of view of the Home investor, the expected utility can be expressed as:

$$
U\left(\alpha^{H}, \alpha^{F}, B\right)=\widetilde{W}-\frac{\widetilde{W^{2}}}{2 \gamma}+I_{\alpha^{H}>\underline{\alpha}}\left(\alpha^{H}\right) g(\lambda, B) \alpha_{C S}^{H}
$$

where $\gamma$ is the risk aversion parameter and $I_{\alpha^{H}>\underline{\alpha}}\left(\alpha^{H}\right)$ is the indicator function equal to 1 if $\alpha^{H}>\underline{\alpha}$ and equal to zero otherwise. It captures the idea that investors can enjoy private benefits of control only by becoming controlling shareholders. The choice variables of an investor are the portfolio shares, $\alpha^{H}$ and $\alpha^{F}$, to be allocated to the domestic and foreign risky assets, respectively, and the amount of private benefits of control to be extracted, $B$, if the investor is a controlling shareholder. Investors' expected utility depends on the expected final period wealth and its variance, which can be written as follows:

$$
\begin{aligned}
& E(\widetilde{W})=W_{0}-\alpha^{H} P-\alpha^{F} P^{*}+\alpha^{H}\left(\mu_{X}-B\right)+\alpha^{F}\left(\mu_{X}^{*}-B^{*}\right) \\
& -I_{\alpha^{H}>0}\left(\alpha^{H}\right) c-I_{\alpha^{F}>0}\left(\alpha^{F}\right) c \\
& \text { (3) } \operatorname{Var}(\widetilde{W})=\left(\alpha^{H}\right)^{2} \sigma_{X}^{2}+\left(\alpha^{F}\right)^{2} \sigma_{X^{*}}^{2}+2 \rho \sigma_{X} \sigma_{X^{*}} \alpha^{H} \alpha^{F} \text {, }
\end{aligned}
$$

where $I_{a>0}(a)$ is an indicator function equal to 1 if $a>0$ and equal to zero otherwise. The expressions for the Foreign investors are similar and are thus omitted.

\section{Equilibrium}

Home and Foreign controlling shareholders and portfolio investors maximize their expected utility, taking other agents' choice variables and prices as given. The markets for both risky assets clear. 


\section{Portfolio choices and extraction of private benefits of control}

\section{A Main results}

In this section, in order to derive a benchmark case, we assume that controlling shareholders collude in the extraction of private benefits. Hence they act as if their share of the company was equal to the sum of their ownership stakes. After having extracted $B$ from the company, the controlling shareholders share the private benefits according to their ownership stakes. These assumptions are similar to Bennedsen and Wolfenzon (2000), who analyze the implications of the joint extraction of private benefits for the optimal sale of a company.

The optimal level of private benefits extracted by controlling shareholders maximizes their expected utility and satisfies the first order condition. For controlling shareholders at Home the first order condition is:

$$
\int \alpha_{C S}^{H} d F\left(w_{0}\right)\left[g_{B}(\lambda, B)-1\right]=0
$$

The assumptions on the extraction technology guarantee that there is always an internal solution to the previous first order condition. The assumptions on the function $g(\lambda, B)$ imply that $\frac{d B}{d \lambda}=$ $-\frac{g_{\lambda B}}{g_{B} B}<0$, i.e. the higher is the level of investor protection, the lower is the level of private benefit extraction.

The intuitive interpretation of the first order condition is the following: The function $g$ may be seen as transforming verifiable cash flow, $B$, into non-verifiable private benefits. Ownership concentration has two opposite effects. On the one hand, a larger ownership stake aligns the incentives of controlling shareholders and portfolios investors, as the controlling shareholders internalize the effect of expropriating a fraction of the cash flow to a larger extent. This is what is commonly indicated as incentive effect of ownership concentration. On the other hand, controlling shareholders with a larger ownership stake can secure control and enjoy a larger fraction of diverted cash flows. To put it differently, there is an entrenchment effect of ownership concentration. Since in this specification the ability to extract private benefits of control conferred by a controlling stake and alignment effect of that ownership stake have opposite effects on the utility for controlling shareholders, the two effects cancel out and the optimal extraction level depends only on quality of investor protection laws. This is the reason why forming a coalition that holds a larger ownership share of the company does not lead to less extraction of private benefits (as it is the case in 
Bennedsen and Wolfenzon, 2000). This also implies that when there are several controlling shareholders with different stakes in the company, everybody agrees on the level of private benefits to be extracted since the level of extraction is independent of ownership stake.

Note also that extraction of private benefits is inefficient in equilibrium, as long as the controlling shareholders or their coalition owns less than 100 percent of the company. In equation (4) the marginal value of security and private benefits is equalized. The inefficiency of extraction of private benefits is due to the fact only controlling shareholders can enjoy private benefits, but all shareholders loose security benefits. Hence, for given value of cash flow diversion, less value is destroyed when ownership is more concentrated. If controlling shareholders owned the whole company, extraction of private benefits would be as efficient as receiving security benefits.

The first proposition summarizes the portfolio decisions of investors with different levels of initial wealth.

Proposition 1 For a given wealth distribution in the domestic and foreign countries, and given prices of the risky assets, the portfolio shares of Home investors with different levels of wealth are:

1. If $W_{0} \leq \underline{\underline{W}}\left(\lambda, \lambda^{*}, P, P^{*}\right)$, then $\alpha_{P I}^{H}=\alpha_{P I}^{F}=0$

2. If $\underline{\underline{W}}\left(\lambda, \lambda^{*}, P, P^{*}\right) \leq W_{0}<\underline{W}\left(\lambda, \lambda^{*}, P, P^{*}\right)$, then $\alpha_{P I}^{H} \leqq \frac{\mu_{X}-B-P}{\gamma \sigma_{X}^{2}}$, and $\alpha_{P I}^{F}=0$, if $\mu_{X}-B-$ $P>\mu_{X^{*}}-B^{*}-P^{*}$

$\alpha_{P I}^{H}=0$ and $\alpha_{P I}^{F} \leqq \frac{\mu_{X^{*}}-B^{*}-P^{*}}{\gamma \sigma_{X}^{2}}$ if $\mu_{X}-B-P<\mu_{X^{*}}-B^{*}-P^{*}$

3. If $\underline{W}\left(\lambda, \lambda^{*}, P, P^{*}\right) \leq W_{0}<\bar{W}\left(\lambda, \lambda^{*}, P, P^{*}\right)$, then $0<\alpha_{P I}^{H} \leq \alpha_{\text {optimal }}^{H}, 0<\alpha_{P I}^{F} \leq \alpha_{\text {optimal }}^{F}$

4. If $\bar{W}\left(\lambda, \lambda^{*}, P, P^{*}\right) \leq W_{0}$, then $\alpha_{C S}^{H} \geqslant \underline{\alpha}>\alpha_{\text {optimal }}^{H}$ and $0 \leq \alpha_{C S}^{F} \leq \alpha_{\text {optimal }}^{F}$

Proof. See the Appendix.

Proposition 1 shows that due to the existence of participation costs and the possibility of extracting private benefits of control, individuals have different incentives to diversify their portfolios depending on the level of initial wealth. Less wealthy individuals have the weaker incentives to invest in the domestic stock market when expected domestic security returns, $\mu_{X}-B-P$, are low. In particular, if security returns are higher in Foreign than at Home (i.e., $\mu_{X}-B-P<\mu_{X^{*}}-B^{*}-P^{*}$ ), individuals with relatively low levels of wealth will invest only in the foreign risky asset.

Controlling shareholders emerge endogenously and the emergence is determined by two factors, investor protection and the wealth distribution. In particular, very wealthy individuals have an 
incentive to over-invest in domestic stocks and become controlling shareholders due to the possibility of enjoying private benefits of control. The incentive is stronger where investor protection is weak, as $g(\lambda, B)$ is larger. Security benefits in the foreign country matter for domestic ownership concentration as much as domestic investor protection. As expected security returns in the foreign country $\left(\mu_{X^{*}}-B^{*}-P^{*}\right)$ increase, it becomes more costly for wealthy individual to forgo benefits from international diversification to acquire control at Home. Hence, domestic extraction of private benefits may decrease as a consequence of an improvement in investor protection abroad.

The incentive to over-invest in domestic stocks by wealthy investors is the mechanism that leads to home equity bias in countries with poor investor protection. Interestingly, private benefits of control can help to explain why French and Poterba (1991) find that, based on the observed portfolio patterns, investors seem to expect returns in their domestic stock market to be several hundred basis points higher than returns in other markets. This finding would be consistent with unobservable private benefits of control: part of the expected returns would be due to expected cash flows and part to private benefits of control. To an outside observer the situation would look like that investors had biased expectations about stock returns, whereas in reality controlling shareholders would get additional returns in the form of private benefits.

Without the incentive to over-invest in order to acquire control there might be a "good country bias" in investor behavior as less wealthy portfolio investors choose to hold stocks in the country that provides higher security benefits (i.e., return to investment net of cash flow diversion). As a consequence, less wealthy portfolio investors may find it optimal not to participate in the domestic stock market and to overweight or even invest only in foreign stocks.

It is useful to note that for given prices an improvement in investor protection at Home has the following effects on the demand for equity. If investor protection improves in the domestic economy, it becomes more lucrative to invest in the domestic risky asset for the less wealthy investors, because domestic stocks' payoffs are higher. If corporate governance at Home becomes better than in Foreign $\left(\lambda>\lambda^{*}\right)$, some individuals, who previously found it optimal to stay out of both of the risky asset markets, are now willing to pay the fixed participation cost $c$ and invest in the domestic stock market. Improved domestic investor protection also increases the incentives to invest in the domestic risky asset compared to investing abroad. Those less wealthy investors that found it optimal to invest only in the foreign stock market may be willing to switch to the domestic market or start investing in the domestic market in addition to the foreign market. Wealthier investors, who participate in both the domestic and the foreign markets, are now willing to invest 
more at home. Finally, better investor protection also means that it is less lucrative to become a controlling investor, because it is harder to enjoy private benefits of control. Note also that, even though portfolio investors are now more willing to invest at home, the home equity bias does not necessarily become more severe. In fact, the very wealthy have now stronger incentives to diversify internationally. Finally, since an increase in $\lambda$ improves payoffs at Home, the demand for the Home risky asset from foreign investors increases.

Until now, we have taken prices as given. Differences in investor protection of course affect the demand of investors with different wealth levels. As a consequence, prices of risky assets at Home and in Foreign are also affected. We need to consider this to determine the equilibrium ownership structure and the level of international diversification.

The prices are determined from the following market clearing conditions:

$$
\begin{aligned}
& \int_{\underline{\underline{\underline{W}}}}^{\bar{W}} \alpha_{P I}^{H}\left(W_{o}, P, P^{*}\right) d F\left(W_{0}\right)+\int_{\underline{\underline{W}}^{*}}^{\bar{W}^{*}} \alpha_{P I^{*}}^{H}\left(W_{o}, P, P^{*}\right) d F^{*}\left(W_{0}\right)+ \\
& \int_{\bar{W}}^{\infty} \alpha_{C S}^{H}\left(W_{o}, P, P^{*}\right) d F\left(W_{0}\right)+\int_{\bar{W}^{*}}^{\infty} \alpha_{C S^{*}}^{H}\left(W_{o}, P, P^{*}\right) d F^{*}\left(W_{0}\right)=1
\end{aligned}
$$

$$
\begin{aligned}
& \int_{\underline{\underline{W^{*}}}}^{\bar{W}^{*}} \alpha_{P I^{*}}^{H}\left(W_{0}, P, P^{*}\right) d F^{*}\left(W_{0}\right)+\int_{\underline{\underline{W}}}^{\bar{W}} \alpha_{P I}^{H}\left(W_{o}, P, P^{*}\right) d F\left(W_{0}\right)+ \\
& \int_{\bar{W}^{*}}^{\infty} \alpha_{C S^{*}}^{H}\left(W_{o}, P, P^{*}\right) d F^{*}\left(W_{0}\right)+\int_{\bar{W}}^{\infty} \alpha_{C S}^{H}\left(W_{o}, P, P^{*}\right) d F\left(W_{0}\right)=1
\end{aligned}
$$

It is not possible to derive prices in closed form without assuming a specific functional form for the distribution of wealth. However, we can derive implications on the relation between equilibrium prices and the level of investor protection, and on stock market participation.

Proposition 2 The relation between the price of the risky asset and quality of investor protection is non-monotonic. If most of the shares are held by wealthy domestic investors, $P\left(P^{*}\right)$ is decreasing (increasing) in $\lambda$.

Proof. See the Appendix.

La Porta et al. (2002) provide evidence that firms are valued more in countries where minority shareholders are well protected. At first sight, this result would imply that the price of the domestic risky asset, $P$, would increase monotonically in the degree of investor protection $\lambda$. However, more careful reading of La Porta et al. (2002) reveals that investor protection affects corporate 
valuations positively only after controlling for the ownership stake of the controlling shareholder. This is exactly what Proposition 2 would imply: the relationship between corporate valuations and investor protection is ambiguous without controlling for the ownership structure, but after controlling for the amount that large shareholders hold (i.e., the demand from the controlling shareholders) valuations are positively related to investor protection.

Proposition 2 also underlines that the consideration of general equilibrium effects may be very important for the analysis of the relationship between ownership structure and firm valuation. Several influential empirical papers (see, for instance, McConnell and Servaes, 1990) have interpreted the positive correlation between company market valuation and existence of blockholders - other than the controlling shareholder - as evidence that these large shareholders limit the extraction of private benefits of control by monitoring the controlling shareholders. ${ }^{11}$ Analogously, a large equity share owned by the largest shareholder has been thought to increase market valuation because it would increase the incentives for the controlling shareholder to maximize future cash flows (Morck et al., 1988). In our model there is no role for monitoring and the alignment effect of ownership cancels out with the amount of private benefits of control that controlling shareholders can enjoy. Nonetheless, stock prices may increase in ownership concentration because of a general equilibrium effect: for some wealth distributions, the demand for a risky asset increases if extracting private benefits of control becomes easier. The stock price increases because some investors try to acquire control using open-market transactions. This effect is similar in spirit to Zingales (1995) who shows in a corporate control context that ownership concentration has an effect on the price of voting shares without any effect on the company's cash flows. We show that this effect may be important even when there are no control contests because in general equilibrium increased demand for stock from wealthy investors reduces the amount of stocks that is available for portfolio investors.

An important consequence of Proposition 2 is that the wealth distribution is important in determining which equilibrium prevails in a country.

Corollary 1 The equilibrium level of ownership concentration and extraction of private benefits of control depends not only on the quality of investor protection, but also on the wealth distribution.

As an illustration, let's consider a country with very low level of investor protection, but very even distribution of wealth and low average level of wealth. We then could have an equilibrium in which no individual is wealthy enough to acquire control rights. Equilibrium prices would be such that individuals would invest in the risky asset without being able to extract private 
benefits of control. Moreover, even if the quality of investor protection were very low, stock market participation would be high. The reason for this is that there would be no diversion of cash flows, and thus investors would have a higher incentive to participate in the risky asset market.

Changes in wealth distribution can also explain why the relation between ownership concentration and investor protection is weaker or does not hold if long periods of time are considered. Morck et al. (2004) report that in Canada at the beginning of the 1900's ownership was highly concentrated and investor protection poor. By the middle of the century, however, widely held firms had become predominant, even though investor protection had not improved. This finding is less surprising if one takes into account that in the same period an expanding middle class capable of investing in shares emerged. Our model suggests that the demand for shares by the middle class increased stock prices and this in turn made it optimal for controlling shareholders to reduce their equity-holdings. Morck et al. (2004) also show that the prevalence of widely held firms in Canada has declined starting from the 1970's. This coincides with the abolition of the inheritance tax in Canada in 1972 and widening inequalities of wealth ${ }^{12}$. The implications of our model are also compatible with the experience of Italy in the same period. Aganin and Volpin (2004) report that Italian listed companies were widely held in the early part of the last century. Ownership became more concentrated only after the Great Depression, when the recession and the high level of inflation had eroded the incomes of the middle class and hence their ability to invest in stocks (Zamagni, 1990). More in general, Rajan and Zingales (2003) demonstrate that there was a great reversal in financial development in Europe, where financial markets were well developed before the World War I and deteriorated afterwards. The negative impact of the Great Depression on the middle class incomes in Europe can contribute to the explanation why this reversal happened.

The model has also other implications. First, return to equity in a country is increasing in the level of investor protection. Second, for given distribution of wealth, households' stock market participation is lower in countries with poor investor protection, since the security benefits from investing in the domestic risky asset are lower. This is proved in Proposition 3.

Proposition 3 Expected security returns at Home, $\mu_{X}-B-P$, are increasing in the level of investor protection, $\lambda$. Hence, domestic investor stock market participation decreases as domestic investor protection gets weaker.

Proof. See the Appendix.

Proposition 3 implies that the return to equity for portfolio investors always decreases, if in- 
vestor protection worsens. This is compatible with the empirical evidence showing that stocks with low level of corporate governance yield lower returns (Gompers et al., 2003) and that stock market returns are positively correlated with overall measures of investor protection (Lombardo and Pagano, 1999).

The intuition behind Proposition 3 is the following: The demand for equity from controlling shareholders increases when investor protection gets weaker, because it becomes easier to extract private benefits of control. If prices have increased as a consequence of the increased demand from controlling shareholders, then the incentive to invest for portfolio investors has unambiguously decreased because expected returns from investing have decreased. As a consequence some portfolio investors must have ceased to invest altogether. If prices have, however, decreased, then the total demand for equity must have decreased. Since we know that, for given prices, controlling shareholders always increase their demand when investor protection gets weaker, then portfolio investors must have decreased their demand. Again this implies that investors to a larger extent than before have decided not to invest in stocks. Hence stock market participation rates decrease, no matter what happens to stock prices.

Proposition 3 is derived for a given wealth distribution. Improvements in investor protection increase domestic investor participation in the domestic stock market to a lesser extent if the wealth distribution is such that few investors have high enough wealth to make it worthwhile to pay the participation costs.

Since domestic and foreign portfolio investors are alike, the following corollary follows immediately from Proposition 3.

Corollary 2 Foreign investors hold less equity in a country with poor investor protection. Conversely, the higher is the quality of investor protection in the Foreign country, the more willing are domestic portfolio investors to invest in Foreign.

Corollary 2 also implies that portfolio investors in countries with poor investor protection are more likely to invest in foreign countries compared to portfolio investors in countries where investors are well-protected. To put it differently, they exhibit a good country bias, even though there is home bias in the aggregate. The home equity bias still holds, because in countries with poor investor protection the wealthiest investors have stronger incentives to forgo the benefits of international diversification and over-invest in domestic stocks.

Interestingly, changes in investor protection at Home affect ownership structure also in Foreign. 
Depending on the initial wealth distribution, this may bring convergence in ownership structures. For example, assume that investor protection improves at Home. As a consequence, some investors will want to give up the possibility of enjoying private benefits of control and will begin to diversity their portfolio internationally to a larger extent. If the group of such investors is large enough, the demand for foreign stocks will increase. Prices of foreign stocks will increase as a consequence and ownership concentration will decrease in Foreign just like at Home, since enjoying private benefits of control has become more expensive also in Foreign.

Convergence in ownership structure, however, it is not the only possible outcome of financial reform in a country. Depending on the initial wealth distribution divergence in ownership structures is possible as well. Assume that the wealth distribution before the improvement in investor protection is such that there are only a few rich controlling shareholders, whose portfolio shares are well above the threshold of $\underline{\alpha}$. After a marginal improvement in investor protection they may well decide to remain controlling shareholders and will increase their holdings of the foreign risky asset to a smaller extent than in the previous case. On the other hand, the portfolio investors, who were initially diversifying their portfolio to a large extent because security benefits in the Home country were lower, will decrease their demand for foreign assets. Some of them may even stop investing in the foreign stock market. If the amount of this type of investors is sufficiently large, demand for the foreign risky asset may decrease following an improvement in investor protection at Home. Consequently, the price of the foreign risky asset will decrease and ownership concentration may increase. Therefore, divergence in ownership structures is also a possible outcome of financial reforms in one country.

The model also helps to analyze the effects of financial reforms on the welfare of different investors. Assume that the simple model was extended with one identical period and further assume that investor protection unexpectedly improves at Home in the intermediate period, after investors have made their portfolio choices but before payoffs are realized. An improvement in investor protection at Home would certainly benefit domestic and foreign portfolio investors, who would have access to higher payoffs and could diversify better their portfolios. The individuals who ex ante did not participate in the financial market and begin to do so after the financial reform also would gain for the same reasons. Interestingly, controlling shareholders would not necessarily loose. Obviously, they would be able to extract less private benefits of control in equilibrium and this would affect negatively their expected utility. However, if the distribution of wealth is such that the total demand for shares increases enough, the controlling shareholders could benefit from the 
capital gains on their current holdings. Hence, we expect to observe less resistance to improvements in investor protection in countries with a large middle class, able to participate in the stock market.

\section{B Extension: one controlling shareholder}

According to our assumptions, several controlling shareholders may form a coalition that extracts private benefits of control without any conflicts of interest among the coalition members. All the controlling shareholders agree on the level of private benefits $B$ to be extracted, since the optimal level of extraction does not depend on the initial wealth levels of the controlling shareholders. For a given level of cash flow that is extracted, the controlling shareholders enjoy private benefits of control in proportion to their ownership stakes. Allowing several large shareholders to form a coalition captures the idea that if several controlling shareholders are present it may be easier to tunnel funds out of the firm, because a coalition with a large ownership stake cannot be easily challenged. Moreover, it may be easier to tunnel funds out of a firm using overpayment for goods and services, if multiple controlling shareholders can collude and exchange favors. ${ }^{13}$ In this context, we have shown that both security and control benefits affect the demand for equity. Stock prices may be higher when several blockholders are present just because the demand for equity is higher, and not because they prevent the principal shareholder from extracting private benefits of control.

The assumption that there are several controlling shareholders that form a coalition, however, is not crucial to our results. An alternative way of modelling is to allow for only one controlling shareholder. In this setup, the wealthiest investor ends with the control of the company, because the expected utility from having control is the largest for that investor. Most importantly, her demand for domestic stocks depends on wealth distribution under general conditions. This is proved in Proposition 4.

Proposition 4 If at maximum only one controlling shareholder is allowed, then the controlling shareholder will be the investor with the highest initial wealth. The ownership stake $a_{C S}$ that is required for control is increasing in the wealth of the second wealthiest investor, if the wealthiest investor were to held some wealth in foreign equity and the risk free asset when several shareholders were allowed to hold control (as in our benchmark case in the previous subsection).

Proof. See the Appendix.

The expected utility of control is largest for the wealthiest investor for two reasons: the private benefits the controlling shareholder is able to enjoy increase in the ownership stake and the oppor- 
tunity costs of not being fully diversified at the lowest for the wealthiest investor. If the expected utility of control is largest for the wealthiest investor, then it is optimal for that investor to always buy a marginally bigger ownership stake than any other investor would find it optimal. In equilibrium, the wealthiest investor has to acquire an ownership stake that makes the second wealthiest investor indifferent between being a controlling shareholder and a portfolio investor. Thus the ownership stake that is needed to have control depends on the amount of wealth the second wealthiest investor has been endowed with and ultimately on the wealth distribution. This implies that in a country where the wealth distribution is more skewed - and where there are relatively more wealthy investors wishing to acquire control - the demand for stocks by the controlling shareholder is larger. Hence the demand effect we utilized in the previous section exists even if there is an unique controlling shareholder. In particular, weak investor protection increases the return for the second wealthiest investor from acquiring control. The wealthiest investor will have to buy a larger share of the company in order to obtain control. This in turn drives up prices for given cash flows, and reduces security returns and portfolio investors' participation, as we have shown in Proposition 3.

\section{Discussion of the hypotheses}

The important assumption driving the results of our model is that the payoff on stock investments is non-linearly increasing in the equity stake for domestic investors: domestic investors who own a large enough fraction of the equity of a company gain control and can extract private benefits of control in addition to security benefits. This makes the payoff from investment for large shareholders higher than the payoff from investment for portfolio investors who can enjoy only security benefits, and explains their different behavior. There is empirical evidence supporting this assumption. Barclay and Holderness (1989) show that in block trades the premium that the buyer is willing to pay is increasing in the percentage of the stock that is purchased, suggesting that the payoff is increasing in the size of the block as well.

Additionally, we also need to assume that the market for portfolio investors and controlling shareholders is not completely segmented. We make the assumption that there is only one market clearing price for the stock. Hence we do not allow for price of blocks of shares to deviate from the open market price of stocks. This assumption is stronger than we actually need. It would suffice for our purposes that controlling shareholders traded both in the open market as well as in the market for controlling blocks. This is in fact what actually happens, since it is cheaper for investors 
with a control interest to assemble part of a block in the open market ${ }^{14}$. As long as controlling shareholders to some extent trade in the open market, their demand has an impact on the stock price portfolio investors pay. Similarly, we assume that there is only one class of shares, so that there is no separation between cash flow and voting rights and hence there are no different stock for portfolio investors and controlling shareholders. This assumption is not very restrictive, since dual shares are far from being predominant. For example, Dyck and Zingales (2003) report for the countries that allow two classes of shares that only 14 percent of companies had dual shares.

These are the only assumptions that we really need to explain why controlling shareholders invest too much in domestic stocks and, at the same time, the domestic and foreign portfolio investors invest too little in domestic equity. All the other assumptions we make are not essential for the results, and are done only for simplicity. All our results would still hold with different utility functions. More importantly, we could assume a different technology for the extraction of private benefits of control. In our specification, both security and control benefits depend linearly on the ownership stake, $\alpha_{C S}^{H}$, so that the optimal level of extraction of private benefits of control does not depend on the ownership stake of the controlling shareholders. In other words, the incentive and entrenchment effects of ownership cancel out each other in determining the level of control benefits to be extracted. This assumption simplifies significantly our computations, without driving our results $^{15}$. If the technology for the extraction of private benefits were non-linear in $\alpha_{C S}^{H}$, the optimal level of private benefits of control extracted in equilibrium would be a function of $\alpha_{C S}^{H}$. The payoff from investing in domestic equity, however, would be higher for controlling shareholders than for the remaining domestic investors, and the incentives to underdiversify portfolios would still be present. Moreover, there is clear empirical evidence (see Claessens et al., 2002) that both the incentive and entrenchment effects of ownership are important, so that including the entrenchment effects into the analysis of extraction of control benefits is perhaps a more realistic way of modelling the issue than considering only the incentive effects of ownership concentration, as Shleifer and Wolfenzon (2002) do.

We also assume that investors take prices as given when they make their portfolio choices. In contrast, the existing literature (see again, Shleifer and Wolfenzon, 2002) generally assumes that a controlling shareholder already exists and chooses the amount of equity to sell to outside investors internalizing the effect on the stock price. Our assumption allows us to analyze under what conditions controlling shareholders emerge in equilibrium. ${ }^{16}$ Moreover, it allows the set of shareholders who are able to extract private benefits of control to vary with the level of investor 
protection and the initial distribution of wealth.

The interpretation of the model can also be generalized. In the exposition, we concentrate on individual investors' direct shareholdings. The analysis would be similar, if we considered indirect shareholdings through mutual funds and mutual funds were not able to distribute private benefits of control to their investors. As a consequence, mutual funds would be rarer in countries with poor legal environment. Khorana, Servaes and Tufano (2003) provide empirical evidence consistent with this.

Finally, we have framed this model as an analysis of two countries with separate stock markets. Another interpretation of this model would be that it deals with different risky assets in a single country. According to this interpretation all outside investors should avoid stocks where extraction

of control benefits is likely because of firm-level corporate governance problems. Interestingly, using individual shareholdings in Swedish companies, Giannetti and Simonov (2003) indeed find that outside investors invest a smaller proportion of their portfolios in companies where extraction of private benefits of control is expected to be larger.

\section{Empirical evidence}

Our model has several implications on the portfolio holdings of different categories of investors in relation to the quality of investor protection. These can be summarized as follows:

1. Ownership is more concentrated in countries with poor investor protection;

2. Foreigners hold less equity in countries with poor investor protection;

3. Households' investor participation rate is lower in countries with poor investor protection;

4. In countries with low investor protection, portfolio investors hold relatively more foreign equity.

The existing literature offers plenty of evidence on the first two points. In particular, the relation between investor protection and ownership concentration has been widely studied. La Porta et al. (1998) provide detailed empirical evidence on the negative relation between ownership concentration and investor protection and also document that countries with more inequality have higher ownership concentration, as we would expect. Although this empirical evidence is compatible with our model, there exist other explanations in the literature that help to rationalize it. Ownership 
concentration can be a substitute for legal protection, when the conflict of interest is between managers and investors, and thus ownership concentration can be optimal in countries where investors are poorly protected. Anecdotal evidence, however, suggests that ownership concentration and lack of international diversification are related. The Financial Times (October 26, 2003) for instance reports that "as pressure mounts on the country's business oligarchs", referring to the government's attempt to improve rule of law in Russia, the controlling shareholders - oligarchs - have began to try to dissolve their domestic equity holdings and to diversify their portfolios internationally.

There exists empirical evidence also in support of the second implication of our model. Dahlquist et al. (2003) show that the prevalence of closely held firms in countries with poor investor protection explains part of the home bias of U.S. investors, and that the world stock portfolio available to investors who are not controlling shareholders is more important than the world market portfolio in explaining the portfolio weights of U.S. investors. This is exactly what our model implies: if investors who can enjoy private benefits of control have a large demand for shares, the holdings of portfolio investors who enjoy only security benefits must be lower as a consequence.

The most original implications of our theory concern the equity-holdings of domestic and foreign portfolio investors. We will now turn to test whether investor protection affect the decision to participate in the domestic market and investors' foreign equity-holdings.

\section{A Participation in the domestic market}

There are hardly any international comparisons of households' portfolio choices. This is mainly due to lack of data, as aggregate financial accounts do not allow to distinguish between the decision of participating in the stock market and the amount invested conditional on participation. In addition, the microeconomic data available in national households' surveys may provide heterogeneous information for different countries, because the samples do not represent equally the population and because the surveys have been done for different purposes. Guiso et al. (2001 and 2003) make a first attempt to compare cross-country differences in stock market participation decisions. Using the household surveys of six countries (France, Germany, Italy, Sweden, U.K., U.S.), they show that there are sizable differences in stock market participation rates across countries and that these differences do not depend on households' characteristics. Differences across countries are actually even larger if households' socioeconomic characteristics that are known to affect the participation decision are controlled for. Moreover, as our model would predict, Guiso et al. find that the main 
differences in stock market participation rates between continental Europe and the U.S. are between the poor and middle-class households, who are significantly less inclined to hold stocks in Europe. Rich households have high participation rates in all countries.

In order to analyze whether the empirical evidence is compatible with the results of our model, we gather data for a larger set of countries, and then analyze whether differences in participation rates are related to differences in investor protection. Our main source of data is the 1999 Share Ownership Survey conducted by the World Federation of Exchanges, which provides data on the fraction of households who directly hold stocks in 1999 for Australia, Austria, Canada, Denmark, Finland, Hong Kong, Japan, New Zealand, Norway, Sri Lanka, the UK, and the US. The data on France, Italy, the Netherlands, and Sweden are taken from Guiso et al. (2003b), which in turn use the national household surveys. The data for Belgium, Germany, Greece, India, Singapore, Taiwan, and Turkey are from the June 2002 Factbook published by the Deutsches Aktieninstitut. Finally, the data on Switzerland, Portugal and Ireland are from national private investment reports, which are respectively: a report of the Marktforschungsinstitut Demoscope, which surveyed a representative sample of 3242 people on their shareholdings activities in 1998, the "Survey into the profile of the Portuguese private investor" from the Comissão do Mercado de Valores Mobilliáros, and the report "Private share ownership in Ireland", published in 2000 by Goodbody Stockbrokers.

\section{[INSERT TABLE I]}

These data measure domestic investors' participation in the domestic stock market. Their main drawback is that we do not have information on indirect holdings, which obviously have an important impact on the diversification of investors' portfolios. Moreover, the data refer to different years: the survey of the World Federation of Exchanges refers is from 1998, the data from Guiso, Haliassos and Jappelli (2003) from 1997 or 1998, the Deutsches Aktieninstitut' data from 2000, the report on Switzerland from 1998, and the reports on Portugal and Ireland from 1999. Although these caveats will have to be kept in mind, we believe that it is valuable to provide some empirical evidence on cross-country differences in household stock market participation rates. Moreover, the lack of information on indirect stockholdings should not bias our results, since Guiso et al. (2003) find that financial intermediaries are less developed in countries where stock market participation is low. Guiso et al. (2003) even argue that the low level of intermediation may explain the low stock market participation rates. 


\section{[INSERT FiguRE I]}

Figure I shows the correlation between stock market participation and the antidirector rights index, measuring investor protection, constructed by La Porta et al. (1998) is positive in our sample. Furthermore, not only the impact of investor protection on stock market participation is positive and significant, but it also explains 48 percent of the variance in stock market participation rates across countries. ${ }^{17}$ Moreover, our model implies that wealth distribution matters. We try to control for this effect using the Gini coefficient of income. ${ }^{18}$ The coefficient of this variable (not reported) is negative as expected: Investor participation is lower in countries with higher inequality. However, the coefficient is not significant. The coefficient of the quality of investor protection remains positive and significant, even after controlling for the income distribution.

We examine how robust these results are to the inclusion of control variables. Investors may participate in the stock market to a greater extent in richer countries. Moreover, investors might also have more incentives to participate in the stock market, the higher is the supply of stocks. When we add GDP per capita as a control variable and control for supply of stocks relative to the size of the economy, by including the ratio of stock market capitalization to GDP, the antidirector measure remains positive and highly significant (at the 1 percent level). The results (not reported) are similar if we also control for the quality of law enforcement. Both high level of law enforcement and shareholder protection increase significantly households' stock market participation rates. Results are also similar if we use alternative measures of investor protection such as a measure of law and order, constructed by the International Country Risk Guide, measuring a country's law and order tradition, or the index constructed by La Porta et al. (2003), measuring the quality of the laws facilitating private enforcement through disclosure and liabilities rules ${ }^{19}$.

\section{B Foreign equity-holdings}

Even more compelling empirical evidence is obtained from the holdings of foreign equity in countries with poor investor protection. According to our model, the home bias of investor portfolios in these countries comes from the large amounts of wealth invested in domestic equity by investors who are able to enjoy private benefits of control. In contrast, the portfolio investors who enjoy only security benefits should have a strong incentive to invest in foreign stocks in countries where domestic investors are poorly protected. We attempt to test this implication of our model using both macro and micro data. 
Aggregate data may be preferable to understand the magnitude of foreign equity-holdings without sample selection biases. On the other hand, aggregate data do not allow to identify the identity of investors and may therefore include the foreign holdings of the controlling shareholders of a country.

The aggregate data we use are compiled by Lane and Milesi-Ferretti (2001) who construct estimates of foreign assets and liabilities and the equity and debt subcomponents for a crosssection of 67 industrial and developing countries. In particular, Lane and Milesi-Ferretti distinguish portfolio equity investments from foreign direct investments, which involve control of production and have very different motivations. We use the measures constructed by Lane and Milesi-Ferretti of foreign equity assets (i.e., domestic holdings of foreign equity) and liabilities (i.e., foreign holdings of domestic equity), which include only portfolio investment. ${ }^{20}$ To measure the portfolio shares of investors who enjoy only security benefits, we also need a measure of their holdings of domestic risky assets. From Dahlquist et al. (2003), we get a measure of the percentage of market capitalization that is closely held. Therefore we can proxy the holdings of domestic and foreign portfolio investors using the percentage of the stock market capitalization that is not closely held. At this point, the share of foreign equity in the portfolios of domestic investors who are not controlling shareholders can be proxied as follows:

$$
\widehat{\alpha_{P I}^{F}}=\frac{\text { Domestic Holdings of Foreign Equity }}{(1-\% \text { Closely Held Market Cap. }) \times \text { Market Cap. }+} .
$$

Note that the main bias in our estimate of $\widehat{\alpha}_{P I}^{F}$ is that it also includes the foreign holdings of controlling shareholders. We must keep this in mind in the interpretation of the empirical evidence.

\section{[INSERT Figure II]}

As an implication of our model we expect $\widehat{\alpha}_{P I}^{F}$ to be larger in countries with low level of investor protection. Figure II shows the mean level of foreign equity shares and the participation rate in countries with different levels of investor protection. ${ }^{21}$ The figure shows that indeed $\widehat{\alpha}_{P I}^{F}$ is lower in countries with high investor protection. The differences emerge also from more rigorous statistical testing: As we would expect on the basis of our model, the portfolio share of foreign equity is significantly lower in countries with high level of investor protection. Furthermore, the size of the 
country's stock market capitalization relative to the world stock market capitalization should also affect the incentives to invest abroad, according to the international capital asset pricing model. When we add the weight of each country's stock market in the world portfolio as a control variable, the antidirector index remains negative and significant (at the 5 percent level). Results are also similar when we use alternative measures of shareholders' rights, such as the private enforcement index.

To test whether a good country bias indeed exists, we need to know in which countries domestic portfolio investors invest. To this end, we use also a micro-level dataset, compiled by Thomson Financial Securities Data (TFSD), which provides information on the equity-holdings of mutual funds - both closed-end and open-end - and other institutional portfolio investors, mainly financial institutions, in over 100 different countries. The dataset includes the total equity holdings of each institutional investor and the equity positions an investor holds in different countries. TFSD gathers the data directly from institutional investors worldwide or from financial market regulators. Our data is the investors' equity holdings as of December 31, 2002 or June 30, 2003, depending on the reporting frequency of an investor. From this dataset we can compute the portfolio shares that all investors from a given country (origin) have in another country (target). ${ }^{22}$ The country of origin is the country where the institutional investor is incorporated. Although more then one hundred countries are included in the sample, investors from a given country often do not invest in another country. We exclude these observations because no investment is most likely due to distance and lack of familiarity and the inclusion of these observations may bias our results. Additionally we include only countries for which we have institutional indicators, market capitalization and GDP per capita. All these requirements reduce the size of the sample considerably. Our final sample includes investments from 61 countries.

\section{[INSERT TABLE II]}

Table II clearly shows that investors based in countries with lower investor protection invest more abroad and that they invest a larger share of their assets in better investor protection countries, as the logarithm of the portfolio share decreases in the level of investor protection in the origin country and increases in the level of investor protection of the destination country. This holds for all three investor protection indices we use. The sample size slightly varies for different specifications because our indices are not defined for all countries.

However, these results do not take into account that different countries differ in the domestic 
supply of financial assets. Domestic investors may be prone to invest abroad not because they chase higher security returns as our model implies but because the supply of assets at Home is too small. Also it is expected that investors invest more in countries like the U.K. or the U.S. because they represent a large part of the world market capitalization. Our preliminary findings could thus spuriously depend on the fact that we do not control for the weight of the target country in the world stock market capitalization. In column 4 of table II, we add several control variables: the market capitalization to GDP of the origin country to control for the supply of assets at Home; the logarithm of the target country's stock market capitalization relative to the world market capitalization; the target country's weight in the world float portfolio, constructed on the free-floating shares available to all investors, which, as suggested by Dahlquist et al. (2003) may represents the correct measure of the supply of stocks to portfolio investors; and the logarithm of the distance between the main financial centres of each pair of countries to control for familiarity ${ }^{23}$. We still find that portfolio investors from weak investor protection countries invest more abroad and that strong investor protection countries receive more foreign investment. ${ }^{24}$ The results are not only statistically, but also economically significant. If the index of private enforcement in the origin country increases by one standard deviation, the logarithm of the portfolio shares invested in foreign countries decreases by almost 10 percent. If then index of private enforcement increases in the target country by one standard deviation, the logarithm of the portfolio share invested increases by 5 percent..

The ability to privately enforce one's own rights is revealed to be more important than laws on the books for foreign investment. This is not surprising as it may be more difficult for foreigners to enforce law on the book and more costly to win in a court if they have the burden of proof. This interpretation is also compatible with the fact that the index of public enforcement constructed by La Porta et al. (2003) does not seem to have any effect on foreigners' stock market participation (results not reported).

Alternative explanations have a hard time in reconciling these empirical findings. Guiso et al. (2003b), for instance, argue that differences in stock market participation rates across countries may depend on differences in participation costs. It may well be that participation costs are higher in countries with poor investor protection. However, a difference in participation costs cannot explain why in countries with low level of investor protection domestic investors hold more foreign equity that in countries with high investor protection, without making an assumption that in countries where investors rights are well protected, the fixed costs associated to buying foreign equity are 
higher than in countries with lower investor protection. Our explanation based on the relative payoff from domestic and foreign investments allows a more coherent explanation of these different aspects of portfolio choices.

\section{Conclusions}

To our knowledge, this is the first paper analyzing the effect of investor protection on the demand for equity. Low degree of investor protection makes it relatively easy for controlling shareholders to expropriate outside investors. This in turn leads to lower security benefits and lower expected returns for portfolio investors and hence leads to lower stock market participation rates in the domestic market. Empirically, we indeed find that differences in investor protection can explain differences in households participation rates across countries.

A novel implication of our model is that portfolio investors have a greater incentive to invest in countries which offer better investor protection. We call this the good country bias. Compatibly with this implication of the model we find that portfolio investors based in weak investor protection countries are more inclined to invest abroad and that they hold equity especially in strong investor protection countries. Nonetheless, deficiencies in investor protection lead to the more familiar home equity bias in the aggregate. All foreign portfolio investors have an incentive to avoid investing in a country where expropriating minority shareholders is easy, while wealthy investors have an incentive to become controlling investors by investing a large proportion of their wealth in the stock market in a country with poor investor protection.

Interestingly, the demand effect, which drives up stock prices in our model, may suggest a rationale why companies may want to issue voting and non-voting shares. Investors buy nonvoting shares exclusively for portfolio reasons. Hence, their price reflects only future cash flows after the extraction of private benefits, and not the demand from investors who wish to acquire control as it is targeted for voting shares. Consequently, having non-voting shares may make it easier to attract portfolio investors, for whom the mere security return of voting shares would be too low. 


\section{References}

Aganin, Alexander and Paolo Volpin, 2004, The history of corporate ownership in Italy, mimeo, London Business School.

Ahearne, A., W. Griever, and F. Warnock, 2001, Information costs and home bias: An analysis of U.S. holdings of foreign equities, working paper no. 691, Federal Reserve Board, International Finance Division.

Barclay, Michael J. and Clifford Holderness, 1989, Private benefits from control of public corporations, Journal of Financial Economics 25, 371-395.

Bennedsen, Morten, and Daniel Wolfenzon, 2000, The balance of power in closely held corporations, Journal of Financial Economics 58, 113-139.

Betton, Sandra, and B. Espen Eckbo, 2000, Toeholds, bid jumps, and expected payoffs in takeovers, Review of Financial Studies 13, 841-882.

Black, Fischer, 1974, International capital market equilibrium with investment barriers, Journal of Financial Economics 1, 337-352.

Brav, Alon, George M. Constantinides, and Christopher C. Geczy, 2002, Asset pricing with heterogenous consumers and limited participation: Empirical evidence, Journal of Political Economy 110, 793-824.

Burkart, Mike, Denis Gromb, and Fausto Panunzi, 1998, Why higher takeover premia protect minority shareholders, Journal of Political Economy 112, 172-204.

Chan, Kalok, Vicentiu Covrig and Lilian Ng, 2003, What determines the domestic bias and foreign bias? Evidence from equity mutual fund allocations worldwide, mimeo, Hong Kong University of Science and Technology.

Claessens, Stijn, Simeon Djankov, and Larry H.P. Lang, 2002, Disentangling the incentive and entrenchment effects of large shareholdings, Journal of Finance 55, 2741-2772.

Coval, Joshua, and Tobias J. Moskowitz, 1999, Home bias at home: Local equity preference in domestic portfolios, Journal of Finance 54, 2045-2073. 
Dahlquist, Magnus, Lee Pinkowitz, René Stulz, and Rohan Williamson, 2003, Corporate governance and the home bias, Journal of Financial and Quantitative Analysis 38, 87-110.

Deiniger, Klaus, and Lyn Squire, 1996, A new dataset measuring income inequality, World Bank Economic Review 10, 565-591.

Demirgüc-Kunt, Asli, and Ross Levine (eds.), 2001, Financial Structure and Economic Growth. A Cross-Country Comparison of Banks, Markets and Development, MIT Press, Cambridge, Mass.

Denis, Diane K. and John J. McConnell, 2003, International corporate governance, Journal of Financial and Quantitative Analysis 38, 1-36.

Dyck, Alexander and, Luigi Zingales, 2003, Private benefits of control: An international comparison, forthcoming Journal of Finance.

Financial Times, 2003, Russia for Sale, October 26, p. 13.

French, Kenneth R., and James M. Poterba, 1991, Investor diversification and international equity markets, American Economic Review 81, 222-226.

Gande, Amar, and David Parsley, 2003, News spillovers in the sovereign debt market, forthcoming Journal of Financial Economics.

Gehrig, Thomas, 1993, An information based explanation of the domestic bias in international equity investment, Scandinavian Journal of Economics 95, 97-109.

Giannetti, Mariassunta, and Andrei Simonov, 2003, Which investors fear expropriation? Evidence from investors' stock picking, CEPR working paper no. 3843.

Glaeser, Edward L., Simon Johnson, and Andrei Shleifer, 2001, Coase versus the Coasians, Quarterly Journal of Economics 116, 853-899.

Gompers, Paul A., Joy L. Ishii and Andrew Metrick, 2003, Corporate governance and equity prices, Quarterly Journal of Economics 118, 107-155.

Gompers, Paul A., Joy L. Ishii and Andrew Metrick, 2004, Incentives vs. control: An analysis of U.S. dual-class companies, NBER working paper no. 10240.

Grinblatt, Mark, and Matti Keloharju, 2000, The investment behavior and performance of various investor-types: A study of Finland's unique data set, Journal of Financial Economics 55, 43-67. 
Guiso, Luigi, Michael Haliassos, and Tullio Jappelli, 2001, Household Portfolios, MIT Press, Cambridge, Mass.

Guiso, Luigi, Michael Haliassos, and Tullio Jappelli, 2003, Household Stockholding in Europe: Where Do We Stand and Where Do We Go?, Economic Policy 18,123-170

Hong, Harrison, Jeffrey D. Kubik, and Jeremy C. Stein, 2002, Social interaction and stock-market participation, forthcoming, Journal of Finance.

Johnson, Simon, Rafael La Porta, Florencio Lopez-de-Silanes, and Andrei Shleifer, 2000, Tunnelling, American Economic Review 90, 22-27.

Kang, Jun-Koo, and René M. Stulz, 1997, Why is there a home bias? An analysis of foreign portfolio equity ownership in Japan, Journal of Financial Economics 46, 3-28.

Kerstetter, Steve, 2002, Rags and Riches: Wealth inequality in Canada, mimeo, Canadian Centre for Policy Alternatives.

Khorana, Ajay, Henri Servaes and Peter Tufano, 2003, The world of mutual funds, Harvard Business School working paper.

Lane, Philip, and Gian Maria Milesi-Ferretti, 2001, The external wealth of nations: Measures of foreign assets and liabilities for industrial and developing countries, Journal of International Economics 55, 263-294.

La Porta, Rafael, Florencio Lopez-de-Silanes, and Andrei Shleifer, 1999, Corporate ownership around the world, Journal of Finance 54, 471-517.

La Porta, Rafael, Florencio Lopez-de-Silanes, Andrei Shleifer, and Robert Vishny, 1997, Legal determinants of external finance, Journal of Finance 52, 1131-1150.

La Porta, Rafael, Florencio Lopez-de-Silanes, Andrei Shleifer, and Robert Vishny, 1998, Law and finance, Journal of Political Economy 106, 1113-1155.

La Porta, Rafael, Florencio Lopez-de-Silanes, Andrei Shleifer, and Robert Vishny, 2000, Investor protection and corporate governance, Journal of Financial Economics 58, 3-27.

La Porta, Rafael, Florencio Lopez-de-Silanes, Andrei Shleifer, and Robert Vishny, 2002, Investor protection and corporate valuation, Journal of Finance 57, 1147-1170. 
La Porta, Rafael, Florencio Lopez-de-Silanes, and Andrei Shleifer, 2003, What works in securities laws?, NBER working paper no.9882.

Lewis, Karen, 1999, Trying to explain home bias in equities and consumption, Journal of Economic Literature 37, 571-608.

Lins, Karl V., 2003, Equity ownership and firm value in emerging markets, Journal of Financial and Quantitative Analysis 38, 159-184.

Lombardo, Davide and Marco Pagano, 1999, Legal determinants of the return on equity, CEPR working paper no. 2275 .

Mankiw, N. Gregory, and Stephen P. Zeldes, 1991, The consumption of stockholders and nonstockholders, Journal of Financial Economics 29, 97-112.

Martin, Philippe, and Helene Rey, 2002, Financial super-markets: Size matters for asset trade, mimeo Princeton University.

McKinsey\&Company, 2003a, Global investor opinion survey: Key findings, http://www.mckinsey.com/practices/corporategovernance/PDF/GlobalInvestorOpinionSurvey2002.pdf.

McKinsey\&Company, 2003b, McKinsey/KIOD survey on corporate governance, http://www.mckinsey.com/practices/corporategovernance/PDF/cg_survey.pdf.

McConnell, John J., and Henri Servaes, 1990, Additional evidence on equity ownership and corporate value, Journal of Financial Economics 27, 595-612.

Morck, Randall, Andrei Shleifer, and Robert W. Vishny, 1988, Management ownership and market valuation: An empirical analysis, Journal of Financial Economics 20, 293-215.

Morck, Randall, Michael Percy, Gloria Tian, and Bernard Yeung, 2004, The rise and fall of the widely held firm in Canada, mimeo University of Alberta.

Nenova, Tatiana, 2003, The value of corporate voting rights and control: A cross-country analysis, Journal of Financial Economics 68, 325-351.

Rajan, Raghuram and Luigi Zingales, 2003, The great reversals: The politics of financial development in the twentieth century, Journal of Financial Economics 69, 5-50. 
Smarzynska, Beata K., and Shang-Jin Wei, 2000, Corruption and composition of foreign direct investment: Firm-level evidence, NBER working paper no. 7969

Stulz, René, 1981, On the effects of barriers to international investment, Journal of Finance 36, 383-406.

Shleifer, Andrei, and Daniel Wolfenzon, 2002, Investor protection and equity markets, Journal of Financial Economics 66, 3-27.

Vissing-Jorgensen, Annette, 2002, Limited asset market participation and the elasticity of intertemporal substitution, Journal of Political Economy 110, 825-853.

Wei, Shang-Jin, 2000, Local corruption and global capital flows, Brookings Papers on Economic Activity.

Wei, Shang-Jin and Yi Wu, 2001, Negative alchemy? Corruption, composition of capital flows and currency crises, NBER working paper no. 8187.

Zamagni, Vera, 1990, Dalla periferia al centro. La seconda rinascita economica dell'Italia, Il Mulino, Bologna.

Zingales, Luigi, 1995, What determines the value of corporate votes?, Quarterly Journal of Economics 110, 1047-1073.

Zwiebel, Jeffrey, 1995, Block investment and partial benefits of corporate control, Review of Economic Studies 62, 161-185. 


\section{A Appendix}

\section{A Proof of proposition 1}

Solving for the optimal portfolio in the mean-variance framework we easily get:

$$
\alpha_{\text {optimal }}^{H}=\frac{\mu_{X}-B-P-\rho \frac{\sigma_{X^{*}}}{\sigma_{X}}\left(\mu_{X^{*}}-B^{*}-P^{*}\right)}{\gamma \sigma_{X}^{2}\left(1-\rho^{2}\right)}
$$

and

$$
\alpha_{\text {optimal }}^{F}=\frac{\left(\mu_{X^{*}}-B^{*}-P^{*}\right)-\rho \frac{\sigma_{X}}{\sigma_{X^{*}}}\left(\mu_{X}-B-P\right)}{\gamma \sigma_{X^{*}}^{2}\left(1-\rho^{2}\right)} .
$$

This portfolio allocation can be achieved if investors can borrow to invest in the foreign and domestic

stock market or if $\alpha_{\text {optimal }}^{F} P^{*}+\alpha_{\text {optimal }}^{H} P+2 c \leq W_{0}$ and the expected utility associated with the optimal allocation is larger than the one from investing either only in the risk free asset or only in the risk free asset and one of the risky assets, notwithstanding the participation costs. However, since we assume that investors can not borrow to invest in the stock market, the constraint $\alpha_{\text {optimal }}^{F} P^{*}+\alpha_{\text {optimal }}^{H} P+2 c \leq W_{0}$ is binding for individuals with low levels of the initial wealth. In this case, the optimal portfolio allocation is obtained solving the constrained optimization problem and comparing the expected utility that can be achieved investing only in the risk free asset, in the risk free asset and the domestic stocks, in the risk free asset and the foreign stocks, and the risk free asset and domestic and foreign stocks. Some tedious algebra shows that the optimal portfolio shares $\alpha_{S}^{H}$ and $\alpha_{S}^{F}$ are weakly increasing in $W_{0}$. This implies that for low levels of the initial wealth the payoff from investing in risky assets may be very low. Therefore, it is always possible to find a lower bound for the initial wealth $\underline{\underline{W}}\left(\lambda, \lambda^{*}, P, P^{*}\right)$ such that it is optimal to choose $\alpha_{S}^{H}=\alpha_{S}^{F}=0$ to save the fixed participation cost $c$. Individuals with initial wealth larger than $\underline{\underline{W}}\left(\lambda, \lambda^{*}, P, P^{*}\right)$ find it optimal to invest in the domestic or foreign equity market depending on which one offer higher security benefits, and spend $c$ (but not $2 c$ ). This is the case for individuals who due to the wealth constraint cannot invest a large amount of wealth in the risky assets and therefore have initial wealth lower than the upper bound $\underline{W}\left(\lambda, \lambda^{*}, P, P^{*}\right)$. Individuals with initial wealth larger than $\underline{W}\left(\lambda, \lambda^{*}, P, P^{*}\right)$ invest in both risky assets and may eventually reach the optimal level of diversification of their portfolios. However, it is possible to find another lower bound on the level of the initial wealth $\bar{W}\left(\lambda, \lambda^{*}, P, P^{*}\right)$, such that individuals with initial wealth larger than $\bar{W}\left(\lambda, \lambda^{*}, P, P^{*}\right)$ maximize utility by forgoing the diversification benefits in favor of the extraction 
of private benefits of control. In this case they obtain a marginal payoff on the domestic risky asset equal to $\mu_{X}-B+g(\lambda, B)$ instead of $\mu_{X}-B$. If the wealth constraint is binding, the investors who choose to acquire control find it optimal to invest all their wealth in the domestic asset. Otherwise, the portfolio shares in domestic and foreign risky assets are, respectively:

$$
\alpha_{C S}^{H}=\frac{\mu_{X}-B+g(\lambda, B)-P-\rho \frac{\sigma_{X^{*}}}{\sigma_{X}}\left(\mu_{X^{*}}-B^{*}-P^{*}\right)}{\gamma \sigma_{X}^{2}\left(1-\rho^{2}\right)}
$$

and

$$
\alpha_{C S}^{F}=\frac{\left(\mu_{X^{*}}-B^{*}-P^{*}\right)-\rho \frac{\sigma_{X}}{\sigma_{X}^{*}}\left(\mu_{X}-B+g(\lambda, B)-P\right)}{\gamma \sigma_{X^{*}}^{2}\left(1-\rho^{2}\right)}
$$

Even if the wealth constraint is not binding the portfolio shares satisfy $\alpha_{C S}^{H} \geq \alpha_{\text {optimal }}^{H}$ and $\alpha_{C S}^{F} \leq$ $\alpha_{\text {optimal }}^{F}$.

\section{B Proof of proposition 2}

If the initial level of investor protection and the distribution of wealth at Home and in Foreign are such that most of the demand for the risky asset comes from wealthy domestic investors, $W_{0} \in\left[\bar{W}\left(\lambda, \lambda^{*}, P, P^{*}\right), \infty\right)$, a decrease in investor protection increases the demand for domestic risky assets by the controlling shareholders, who are not wealth constrained, and increases the amount of domestic portfolio investors, who will want to become controlling shareholders as $\frac{d \bar{W}\left(\lambda, \lambda^{*}\right)}{d \lambda}>0$. The remaining investors, who find it optimal not to acquire control will, of course, reduce their demand for the domestic risky asset. However, depending on the wealth distribution, the aggregate demand for the domestic risky asset at current prices increases if ex ante portfolio investors were demanding a sufficiently low amount of domestic stocks. It is always possible to find a wealth distribution such that this is true. In this case, $P$ will increase in equilibrium, if investor protection worsens. Also, the demand for the foreign risky asset from domestic investors, who now become controlling shareholders, decreases. If foreign investors held a negligible amount of domestic assets before the decrease in investor protection, their demand for foreign assets does not increase significantly, and therefore $P^{*}$ decreases. 


\section{Proof of proposition 3}

From Proposition 2 we know that the relation between domestic asset prices and quality of law is non-monotonic. This implies that stock prices may either increase or decrease when investor protection becomes weaker. Assume first that $P$ increases as investor protection becomes weaker. In this case, the expected security return from investment, $\mu_{X}-B-P$, decreases unequivocally. Therefore, the wealth of the marginal investor who is indifferent between buying domestic stocks or not increases. This effect is reinforced by the change in the price of foreign stocks, $P^{*}$. Since the security benefits decrease at Home and increase in Foreign, fewer domestic portfolio investors will participate in the domestic market and more of them will buy foreign stocks.

Consider now the case in which $P$ decreases as investor protection gets weaker. By contradiction, assume that $\mu_{X}-B-P$ increases and therefore portfolio investor participation increases. This implies that demand for the domestic risky asset by portfolio investors increases. Since when investor protection gets weaker, the demand for stocks from controlling investors increases and more individuals wish to become controlling investors, this would imply that all investors increase their demand for domestic stocks. In equilibrium, the price for domestic stocks would therefore increase. Since this is a contradiction, we can conclude that investor participation in the domestic market decreases and $\mu_{X}-B-P$ decreases as well.

As before, $P$ actually decreases only if the fraction of initial wealth invested in the domestic market decreases. Hence, the fraction of initial wealth invested in the foreign market must increase and $P^{*}$ increases because of the increased participation in the foreign market.

\section{Proof of proposition 4}

Let's define $W_{\max }$ and $W_{\max }$ - as the wealth of the wealthiest and the second wealthiest individual, respectively. The wealthiest individual's control is not contestable if she invests an amount $\widetilde{\alpha}_{C S}$ such that the expected utility of second wealthiest individuals from investing $\widetilde{\alpha}_{C S}$ and acquiring control is lower than the expected utility from diversifying his portfolio and enjoying only security benefits. This can be written as follows:

$$
E\left[U_{W_{\max -}}\left(\widetilde{\alpha}_{C S} \mid \text { control }\right)\right] \leq E\left[U_{W_{\max -}}\left(\alpha_{P I}^{*} \mid \text { no control }\right)\right]
$$

It is optimal for the richest shareholder to acquire control if:

$$
E\left[U_{W_{\max }}\left(\widetilde{\alpha}_{C S} \mid \text { control }\right)\right]>E\left[U_{W_{\max }}\left(\alpha_{P I}^{*} \mid \text { no control }\right)\right] \text {. }
$$


From the solution of the constrained optimization problem under the budget constraint and the

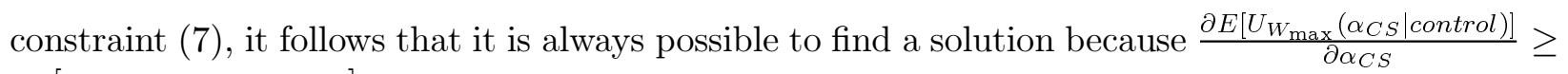

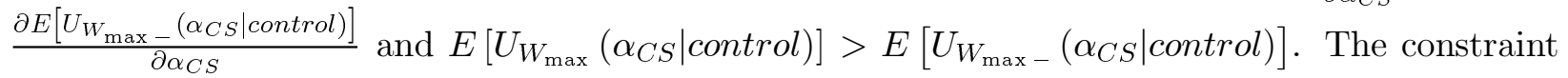
(7) is not binding if the controlling shareholder invests all her wealth in domestic stock. In this case, the controlling stake depends only on the wealth of the wealthiest investor but not on the wealth of the second wealthiest investor. To this extent, ownership concentration does not depend on wealth distribution in equilibrium if the controlling shareholder does not find it optimal to hold the risk free asset or the foreign stock in the optimization problem without the constraint (7). 


\section{Notes}

1. For an overview of the approach and results, see La Porta et. al (2000).

2. Dyck and Zingales (2003) show that blocks of shares that give control are priced higher than shares sold in the open markets and that block premium is negatively related to investor protection. Nenova (2003) shows that superior voting shares demand a premium and that the premium is again negatively related to investor protection.

3. For example, for the U.S., Ahearne et al. (2001) document that at the end of 1997, U.S. stocks comprised $48.3 \%$ of the world market portfolio, yet U.S. investors only invested $10.1 \%$ of their stock portfolios abroad.

4. Black (1974) and Stulz (1981) model barriers to international investments as taxes paid on foreign holdings.

5. Gehrig (1993) derives the optimal portfolio when foreign investors know less than domestic investors and shows that this leads to overweighing domestic stocks. Kang and Stulz (1997) provide evidence consistent with this model.

6. In a recent paper Hong et al. (2002) provide an interesting explanation how social interaction affects investment patterns. In their model, there are two kinds of investors, social and non-social investors. Social investors find it more attractive to invest, if a lot of other people are interested in investing, whereas the returns from investing for non-social investors are independent of other investors' behavior. This may lead to variations in participation rates in stock markets across countries and also to preference for local stocks. However, it cannot explain why sophisticated foreign investors, like financial institutions, are reluctant to invest abroad.

7. We do not consider that foreign investors may also control companies. This is consistent with the literature on home equity bias (see Lewis, 1999, for a survey) which takes into account only foreigners' portfolio equity-holdings. Foreign holdings that involve control are usually classified as foreign direct investment and are studied separately. It is beyond the scope of this paper to study the effects of investor protection on foreign direct investment.

8. The assumption that there are several controlling shareholders that collude in expropriating outside shareholders is not crucial. An alternatively arrangement would be an auction for the exclusive right to control a company. In that arrangement the wealthiest shareholder would always end up being the controlling shareholder. We explore this arrangement in section IV.B.

9. This assumption is done for simplicity only. The qualitative results would not change if private benefits were $e x$ ante uncertain, although the algebra would become more cumbersome.

10. These assumptions can be considered a reduced form of Zwiebel (1995), who studies the strategic interaction among controlling shareholders in a partial equilibrium model and derives a theory of divisible control benefits. We abstract from strategic interactions in order to focus on the general equilibrium implications of private benefits extraction.

11. In a recent paper Lins (2003) shows that non-management blockholders increase firm valuations especially in countries with weak investor protection laws. Lins (2003) interprets this finding as a evidence that blockholders limit the extraction of control benefits. The alternative interpretation would be that increased firm valuations are due to 
increased demand from large shareholders.

12. For the widening inequality in wealth in Canada, see Kerstetter (2002).

13. See Johnson et al. (2000) for descriptions of mechanisms shareholders use to tunnel funds out of firms.

14. For example, in the context of takeovers Betton and Eckbo (2000) show that bidders, who by definition have a control interest, are likely trade in the open market by acquiring a toehold before launching a takeover bid. In a comprehensive sample of U.S. 1353 takeover contests Betton and Eckbo (2003) show that the initial bidder has a positive toehold in 54 percent of cases and a significant toehold comprising of more than 10 percent of shares in 36 percent of cases.

15. Without this assumption we could not determine $\alpha_{C S}^{H}$ explicitly.

16. If we had a controlling shareholder who internalizes the effect on prices when selling equity, there would be another force leading to ownership concentration, due to the fact that an increase in supply of stocks depresses prices (see Martin and Rey, 2002 on this point).

17. It is worthwhile to note that the anti-director rights index we use is predetermined with respect to the participation rates we observe. In fact, La Porta et al. (1997) compute the index for the first half of the nineties, while households' participation rates increased dramatically in the second half of the decennium (Guiso et al., 2003). Hence, it is very unlikely that in countries with high participation rates households lobbied for investor protection. Nor can the results on foreign holdings we present in the next subsection be subject to this criticism, as foreigners cannot vote to support improvements in investor protection.

18. The data on the Gini coefficient of income we use have been compiled by Deininger and Squire (1996). Ideally, we would like to use the Gini coefficient of wealth. However, we have not been able to find that for a large cross-section of countries.

19. La Porta et al. (2003) find some evidence that public enforcement is important when bureacracies are wellfunctioning, whereas private enforcment is always important in explaining financial development.

20. The measure of foreign equity we include is very unlikely to include any wealth that individuals illegally keep abroad to avoid taxes in the domestic country. Hence, our results should not depend on the fact that individuals often invest abroad to avoid taxes.

21. We include Belgium, the only country in the sample for which the index of shareholder protection is equal to 0, in the same group of the countries with index of shareholder protection equal to 1.

22. Chan, Covrig and $\mathrm{Ng}$ (2003) use an earlier version of the dataset.

23. These data are calculated as in Gande and Parsley (2003). We thank David Parsley for providing us with the data.

24. In alternative specifications we do not report we also control a proxy of access to foreign capital markets from 
a given country, and extent of foreign ownership restrictions and accounting standards in the target country. The effect of our variables of interest remains qualitatively invariant. 
Table I. Data

This table presents the data used in figures 1 and 2. Investor stock market participation rates are from 1999 Share Ownership Survey by the World Federation of Exchanges, Guiso et al. (2003), June 2002 Factbook published by the Deutsches Aktieninstitut, Marktforschungsinstitut Demoscope, Comissão do Mercado de Valores Mobilliáros, and Goodbody Stockbrokers. Antidirector rights index is from La Porta et al. (1998). The index ranges from 0 to 5 and higher numbers indicate better shareholder protection. Stock market capitalization and GDP numbers are from Demirgüc-Kunt and Levine (2001). Percentages for closely held stocks are from Dahlquist et al. (2003). The estimate for foreign equity holdings by domestic investors relative to their stock market wealth uses data for foreign equity assets and liabilities from Lane and Milesi-Ferretti (2001).

\begin{tabular}{|c|c|c|c|c|c|}
\hline Country & $\begin{array}{c}\text { Investor } \\
\text { Stock } \\
\text { Market } \\
\text { Participation } \\
\text { Rates } \\
\end{array}$ & $\begin{array}{l}\text { Antidirector } \\
\text { Rights } \\
\text { Index }\end{array}$ & $\begin{array}{c}\text { Stock Market } \\
\text { Capitalization } \\
\text { to GDP }\end{array}$ & $\begin{array}{c}\text { Percentage } \\
\text { Of Market } \\
\text { Capitalization } \\
\text { Closely Held }\end{array}$ & $\begin{array}{c}\text { Foreign } \\
\text { Equity } \\
\text { Holdings by } \\
\text { Domestic } \\
\text { Investors } \\
\end{array}$ \\
\hline Australia & 0.404 & 4 & 0.431048 & 24.85 & 0.009168 \\
\hline Austria & 0.056 & 2 & 0.07132 & 54.85 & 0.0890267 \\
\hline Belgium & 0.05 & 0 & 0.258044 & 47.14 & 0.0799656 \\
\hline Canada & 0.25 & 5 & 0.455363 & 48.82 & 0.0255211 \\
\hline Denmark & 0.28 & 2 & 0.223052 & 25.1 & 0.0362815 \\
\hline Finland & 0.187 & 3 & 0.184352 & 23.49 & 0.009845 \\
\hline France & 0.15 & 3 & 0.197739 & 37.98 & 0.0205537 \\
\hline Germany & 0.089 & 1 & 0.186379 & 44.74 & 0.0489564 \\
\hline Greece & 0.102 & 2 & 0.081025 & 75.18 & \\
\hline Hong Kong & 0.138 & 5 & 1.28219 & 42.73 & \\
\hline India & 0.033 & 5 & 0.132123 & 40.32 & \\
\hline Ireland & 0.17 & 4 & 0.265648 & 13.06 & \\
\hline Italy & 0.07 & 1 & 0.118725 & 37.54 & 0.0205104 \\
\hline Japan & 0.297 & 4 & 0.730083 & 38.38 & 0.0058784 \\
\hline Netherlands & 0.14 & 2 & 0.409205 & 37.74 & 0.0393687 \\
\hline New Zealand & 0.31 & 4 & 0.404699 & 77.48 & 0.0088756 \\
\hline Norway & 0.21 & 4 & 0.151912 & 41.07 & \\
\hline Portugal & 0.145 & 3 & 0.077534 & 35.04 & 0.0089229 \\
\hline Singapore & 0.083 & 4 & 1.23063 & 57.1 & \\
\hline Sri Lanka & 0.023 & 3 & 0.129598 & 19.15 & \\
\hline Sweden & 0.22 & 3 & 0.380937 & 20.99 & 0.029502 \\
\hline Switzerland & 0.176 & 2 & 0.705946 & 25.73 & 0.0566265 \\
\hline Taiwan & 0.125 & 3 & 0.4886 & 22.26 & \\
\hline Turkey & 0.012 & 2 & 0.061429 & 70.86 & \\
\hline UK & 0.3 & 5 & 0.762871 & 9.93 & 0.0149091 \\
\hline US & 0.26 & 5 & 0.581779 & 7.94 & 0.0051064 \\
\hline
\end{tabular}


Table II. Institutional investors' holdings of foreign equity.

The dependent variable is the logarithm of (aggregate) proportion of equity relative to total holdings of equity that institutional investors incorporated in the origin country invests in the target country as of December 31, 2002 or June 30, 2003. Private enforcement index is from La Porta et al. (2003). Shareholder rights (measured by the antidirector index) is from La Porta et al. (1998). Law and order is an indicator of law and order tradition, constructed by the International Country Risk Guide. Market capitalization weight is the logarithm of the target country's stock market capitalization divided by the world stock market capitalization as of December 31, 2002 using data from World Federation of Exchanges. Free float market capitalization weight is the free-float of target country relative to freefloat world stock market capitalization as of December 31, 2002 using the proportion of closely held shares as in Dahlquist et al. (2003). Market capitalization relative to GDP is the stock market capitalization divided by the GDP in the origin countries, divided by $1,000,000$. Logarithm of distance measures the distance between the domicile of the main stock exchange in the origin country and the domicile of the main stock exchange in the target country. T-statistics are in parentheses. ***, **,* denote that a coefficient is significant at the $1 \%, 5 \%$, and $10 \%$ levels, respectively. The standard errors have been computed using the Huber-White estimator of the variance, which produces consistent standard errors even in presence of heteroskedasticity. Observations have been clustered by country of origin.

\begin{tabular}{|c|c|c|c|c|c|}
\hline Explanatory variable & $(1)$ & $(2)$ & $(3)$ & $(4)$ & $(5)$ \\
\hline Private enforcement - target & $\begin{array}{c}3.68^{* * *} \\
(9.56)\end{array}$ & & & $\begin{array}{l}0.44 * * \\
(2.03)\end{array}$ & $\begin{array}{c}0.96^{* * *} \\
(4.05)\end{array}$ \\
\hline Private enforcement - origin & $\begin{array}{c}-1.31 * * * \\
(-3.54)\end{array}$ & & & $\begin{array}{c}-1.07 * * * \\
(-5.05)\end{array}$ & $\begin{array}{c}-1.38 * * * \\
(-5.24)\end{array}$ \\
\hline Shareholder rights - target & & $\begin{array}{l}0.17 * * * \\
(2.63)\end{array}$ & & & $\begin{array}{c}-0.17 * * * \\
(-4.71)\end{array}$ \\
\hline Shareholder rights - origin & & $\begin{array}{l}-0.13 * * \\
(-2.34)\end{array}$ & & & $\begin{array}{l}0.05 \\
(1.36)\end{array}$ \\
\hline $\begin{array}{l}\text { Law and order- target } \\
\text { Law and order- origin }\end{array}$ & & & $\begin{array}{c}1.09^{* * *} \\
(19.73) \\
-0.161^{*} \\
(-1.88)\end{array}$ & & \\
\hline Market cap. weight - target & & & & $\begin{array}{l}1.30 * * * \\
(29.05)\end{array}$ & $\begin{array}{l}1.30 * * * \\
(29.43)\end{array}$ \\
\hline Free-float mkt. cap weight - target & & & & $\begin{array}{c}-6.47 * * * \\
(-3.40)\end{array}$ & $\begin{array}{c}-5.86 * * * \\
(-3.12)\end{array}$ \\
\hline Mkt. cap relative to GDP - origin & & & & $\begin{array}{l}7.75^{* * * *} \\
(9.40)\end{array}$ & $\begin{array}{c}7.85^{* * *} \\
(9.66)\end{array}$ \\
\hline Log. distance & & & & $\begin{array}{c}-0.69 * * * \\
(-15.28) \\
\end{array}$ & $\begin{array}{r}-0.67 * * * \\
(-14.26) \\
\end{array}$ \\
\hline Number of observations & 985 & 1173 & 1063 & 964 & 964 \\
\hline R-squared & 0.10 & 0.01 & 0.14 & 0.68 & 0.69 \\
\hline
\end{tabular}


Figure I. Antidirector Rights vs. Investor Participation

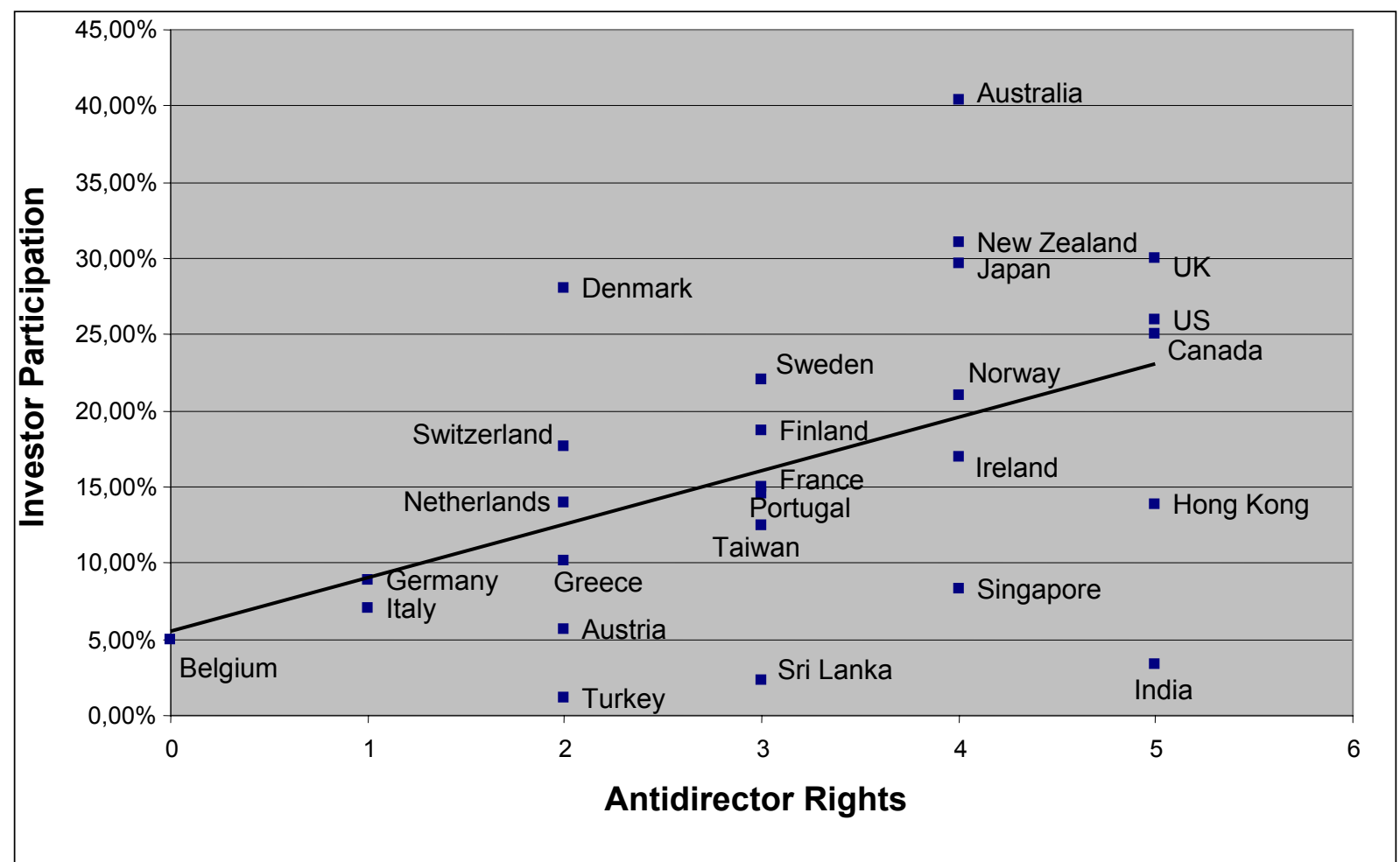


Figure II. Participation Rates, Foreign Equity Holdings and Antidirector Rights

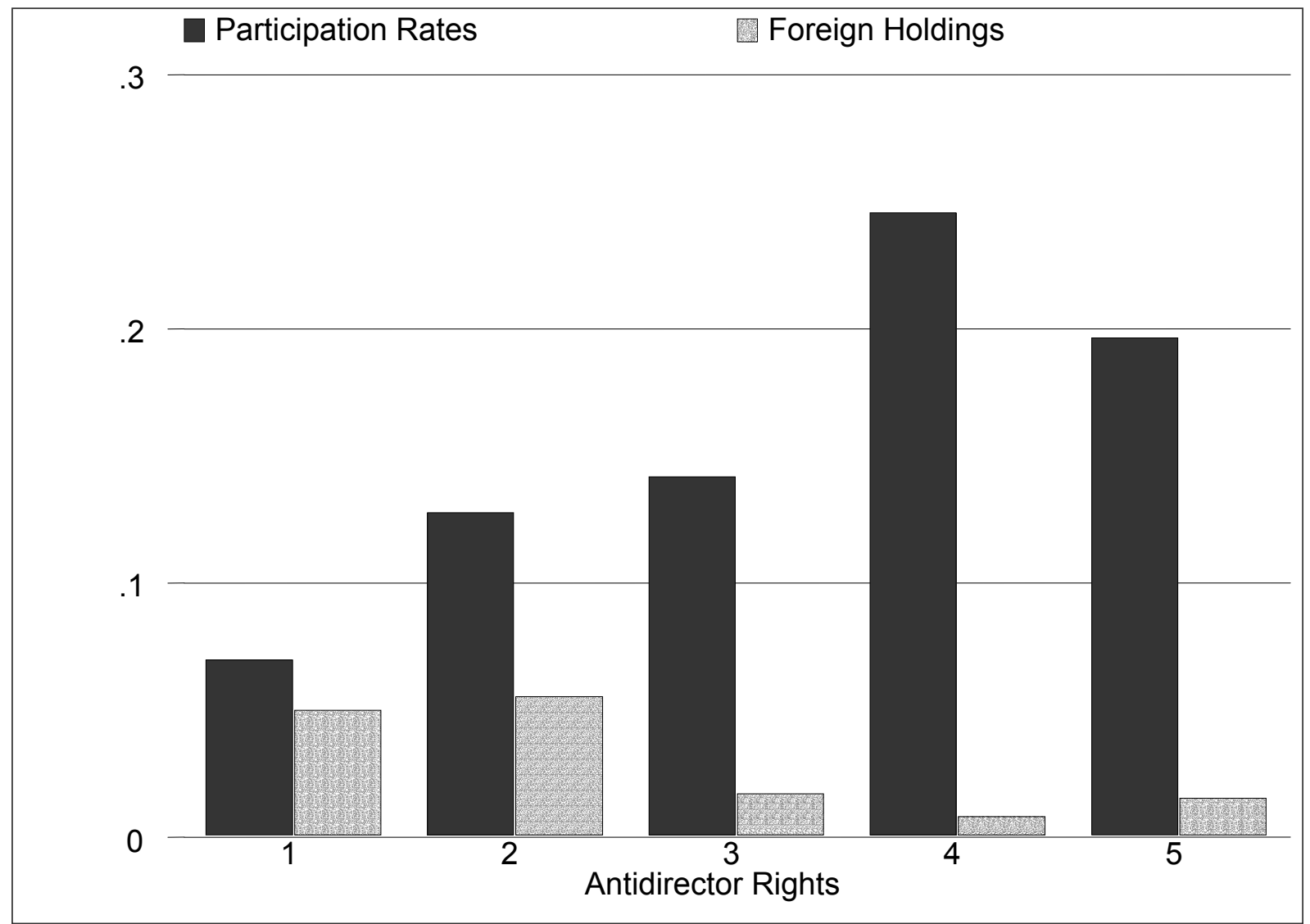

